\title{
Sensitivity of modeled atmospheric nitrogen species and nitrogen deposition to variations in sea salt emissions in the North Sea and Baltic Sea regions
}

\author{
Daniel Neumann $^{1}$, Volker Matthias ${ }^{1}$, Johannes Bieser ${ }^{1,2}$, Armin Aulinger ${ }^{1}$, and Markus Quante ${ }^{1}$ \\ ${ }^{1}$ Helmholtz-Zentrum Geesthacht, Institute of Coastal Research, Max-Planck-Straße 1, 21502 Geesthacht, Germany \\ ${ }^{2}$ Deutsches Zentrum fúr Luft- und Raumfahrt (DLR), Institute of Atmospheric Physics, Oberpfaffenhofen, \\ 82234 Weßling, Germany
}

Correspondence to: Daniel Neumann (daniel.neumann@hzg.de)

Received: 25 September 2015 - Published in Atmos. Chem. Phys. Discuss.: 30 October 2015

Revised: 3 February 2016 - Accepted: 23 February 2016 - Published: 8 March 2016

\begin{abstract}
Coarse sea salt particles are emitted ubiquitously from the ocean surface by wave-breaking and bubblebursting processes. These particles impact the atmospheric chemistry by affecting the condensation of gas-phase species and, thus, indirectly the nucleation of new fine particles, particularly in regions with significant air pollution. In this study, atmospheric particle concentrations are modeled for the North Sea and Baltic Sea regions in northwestern Europe using the Community Multiscale Air Quality (CMAQ) modeling system and are compared to European Monitoring and Evaluation Programme (EMEP) measurement data. The sea salt emission module is extended by a salinity-dependent scaling of the sea salt emissions because the salinity in large parts of the Baltic Sea is very low, which leads to considerably lower sea salt mass emissions compared to other oceanic regions. The resulting improvement in predicted sea salt concentrations is assessed. The contribution of surf zone emissions is considered separately. Additionally, the impacts of sea salt particles on atmospheric nitrate and ammonium concentrations and on nitrogen deposition are evaluated.

The comparisons with observational data show that sea salt concentrations are commonly overestimated at coastal stations and partly underestimated farther inland. The introduced salinity scaling improves the predicted Baltic Sea sea salt concentrations considerably. The dates of measured peak concentrations are appropriately reproduced by the model. The impact of surf zone emissions is negligible in both seas. Nevertheless, they might be relevant because surf zone emissions were cut at an upper threshold in this study. Deacti-
\end{abstract}

vating sea salt leads to minor increases in $\mathrm{NH}_{3}+\mathrm{NH}_{4}^{+}$and $\mathrm{HNO}_{3}+\mathrm{NO}_{3}^{-}$and a decrease in $\mathrm{NO}_{3}^{-}$concentrations. However, the overall effect on $\mathrm{NH}_{3}+\mathrm{NH}_{4}^{+}$and $\mathrm{HNO}_{3}+\mathrm{NO}_{3}^{-}$ concentrations is smaller than the deviation from the measurements. Nitrogen wet deposition is underestimated by the model at most stations. In coastal regions, the total nitrogen deposition (wet and dry) is considerably affected by sea salt particles. Approximately 3-7\% of atmospheric nitrogen deposition into the North Sea is caused by sea salt particles. The contribution is lower in the Baltic Sea region.

The stations in the EMEP network provide a solid basis for model evaluation and validation. However, for a more detailed analysis of the impact of sea salt particles on atmospheric nitrogen species, size-resolved measurements of $\mathrm{Na}^{+}, \mathrm{NH}_{4}^{+}$, and $\mathrm{NO}_{3}^{-}$are needed.

\section{Introduction}

Atmospheric sea salt particles are generated from saline water droplets emitted from the sea surface by wind-governed processes and the breaking of waves. Sea salt particle generation is influenced by sea surface temperature, salinity, and the composition of the sea surface micro-layer (Martensson et al., 2003; Jaeglé et al., 2011; Gantt et al., 2011). It is considerably enhanced in the surf zone, where waves break along the coast. 
Sea salt particles affect the abundance and chemistry of atmospheric pollutants in various ways. Gas-phase species condense on coarse sea salt particles instead of nucleating as new ones and undergo heterogeneous reactions on the particle surfaces (Seinfeld and Pandis, 2006, Chp. 10.4.4 and 10.4.6). Coarse particles have higher dry deposition velocities than fine particles, which leads to faster dry deposition of those species adhering to the course particles. Additionally, hydrochloric acid $(\mathrm{HCl})$ is released from sea salt particles, which affects ozone chemistry in polluted marine air (Cai et al., 2008; Crisp et al., 2014; Knipping and Dabdub, 2003). The effect of sea salt particles on atmospheric chemistry is most relevant in coastal regions where anthropogenic and natural land-emitted species and sea salt particles coincide.

The North and Baltic Sea regions are areas of high anthropogenic activity, including heavy industry, shipping, road transport, agriculture, power generation, and residential heating. These activities emit various air pollutants, such as $\mathrm{NO}_{x}$, $\mathrm{SO}_{2}, \mathrm{NH}_{3}$, and particulate matter. Although emissions have been reduced over the past 30 years (Lövblad et al., 2004; Crippa et al., 2015), their effects on human health and their environmental impact are still significant. In this air pollution regime, sea salt is expected to play an important role in affecting the deposition and heterogeneous chemistry of relevant pollutants. The target of this study was to evaluate the following questions for the central European domain using the EPA's Community Multiscale Air Quality (CMAQ) modeling system:

a. What effects do sea salt emissions have on atmospheric ammonium and nitrate concentrations and on nitrogen deposition?

b. How strongly do surf zone emissions contribute to total sea salt and what influence do these emissions have on (a)?

c. Are sea salt emissions well represented in CMAQ for this region?

These analyses were conducted by setting up four sea salt emission cases and comparing the model results to each other and to European Measurement and Evaluation Program (EMEP) measurement data. Manders et al. (2010) recently evaluated sea salt measurements from various EMEP stations. Modeling air quality in the Eastern Mediterranean Sea using CMAQ, Im (2013) found a strong impact of sea salt emissions on atmospheric nitrate concentrations and considered surf zone emissions to be important. Liu et al. (2015) also found a large impact of sea salt particles on nitrate in a modeling study in the Pearl River Delta, China.

In models, sea salt emissions are parameterized by wind speed and other meteorological and oceanic parameters. Several current parameterizations are based on the wind dependence derived by Monahan and Muircheartaigh (1980) and
Monahan et al. (1986). Spada et al. (2013) and Lewis and Schwartz (2004) provided a useful overview and comparison of available sea salt emission parameterizations. Additionally, Jaeglé et al. (2011) and Ovadnevaite et al. (2014) recently published improved approaches that include wind speed, salinity, sea surface temperature (SST), and wave data. However, sea salt emissions are still not well parameterized in the surf zone, an area of increased wave breaking along the coastline. CMAQ employs a parameterization published by Gong (2003) that expands the Monahan et al. (1986) parameterization to smaller particle diameters. This study adds a dependence on salinity.

\section{Materials and methods}

\subsection{Target region}

The study region is located in the northeastern corner of the Atlantic Ocean and includes the North Sea and Baltic Sea. The North Sea is directly connected to the Atlantic Ocean via the English Channel to the southwest and via the Norwegian Sea to the north. The English Channel is a region of major shipping activity because nearly all ships traveling from outer Europe to the large North European ports, such as Antwerp, Rotterdam, and Hamburg, pass through it. In addition to shipping, considerable anthropogenic activity occurs on land, such as industry, agriculture, and road traffic. The North Sea has a salinity of approximately $35 \%$, which is similar to the Atlantic Ocean. The Baltic Sea is connected to the North Sea via a natural passage between Denmark and Norway/Sweden. In the Baltic Sea, the salinity is approximately $20 \%$ in the western parts and decreases to below $8 \%$ in the eastern parts. During winter, northeastern parts of the Baltic Sea are covered by sea ice. High anthropogenic activity also occurs on the land and water. However, shipping activity is not as pronounced as in the North Sea.

\subsection{Model setup}

The simulations were performed with the CMAQ modeling system, which was developed and maintained by the US EPA. Version 5.0.1 was used for this study. The cb05tucl mechanisms, i.e., the Carbon Bond 05 mechanism by Yarwood et al. (2005) with updated toluene (Whitten et al., 2010) and chlorine chemistry (Tanaka et al., 2003; Sarwar et al., 2007), represented the gas-phase chemistry. Heterogeneous chemistry is covered by the AERO05 mechanism, which is based on the ISORROPIA 1.7 (Nenes et al., 1998, 1999) mechanism. Among other processes, this mechanism governs the condensation of $\mathrm{HCl}, \mathrm{NH}_{3}, \mathrm{HNO}_{3}$, and $\mathrm{H}_{2} \mathrm{SO}_{4}$ on particles and the nucleation of new particles. $\mathrm{HCl}$, $\mathrm{NH}_{3}$, and $\mathrm{HNO}_{3}$ may evaporate back into the gas phase, whereas $\mathrm{H}_{2} \mathrm{SO}_{4}$ does not. The aerosol phase is modeled by three lognormal-distributed modes that are each represented by three moments (Binkowski and Roselle, 2003). 


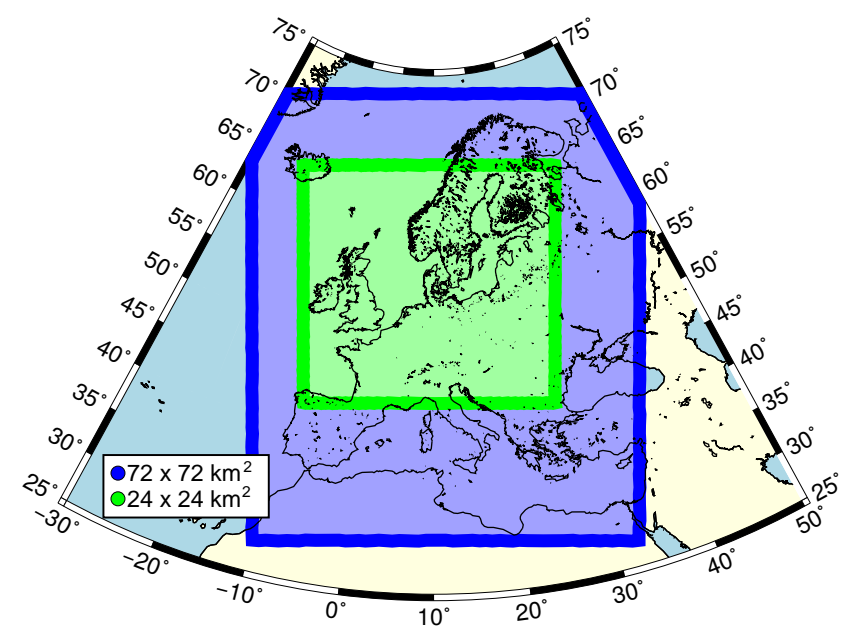

Figure 1. Study region and size of the model grids. The coarse grid (blue) includes Europe and parts of northern Africa. The first nested grid (green) includes northwestern Europe, including the North and Baltic seas.

The AERO05 mechanism is described in the CMAQ Wiki (http://www.airqualitymodeling.org/cmaqwiki). CMAQ also includes in-cloud chemistry.

The study region is covered by a grid with a resolution of $24 \mathrm{~km} \times 24 \mathrm{~km}$ and is enclosed by a grid with a resolution of $72 \mathrm{~km} \times 72 \mathrm{~km}$ covering Europe (Fig. 1). The boundary conditions of the outer grid are taken from monthly means of the TM5 global chemistry transport model system (Huijnen et al., 2010), and the boundary conditions of the $24 \mathrm{~km}$ grid are taken from the enclosing $72 \mathrm{~km}$ grid. Wind-blown dust is not included in the outer boundary conditions.

Two 3-month periods - January to February and July to August 2008 - denoted as winter and summer, respectively, are considered. No model input data were available for December 2007, and no German EMEP measurement data were available for September to December 2008. Therefore, it was decided to represent winter and summer by 2 months each. A 10-day spin-up phase, which was initiated from standardized spatially homogeneous initial conditions, preceded each of the two periods.

\subsection{Input data}

Meteorological input data were calculated by COSMO-CLM (Consortium for Small-scale Modeling in Climate Mode) version 4.8 on a rotated long-lat grid of $0.22^{\circ}$ resolution with hourly output (Geyer and Rockel, 2013; Geyer, 2014). The model grid covers Europe, parts of Greenland, and the southern coast of the Mediterranean Sea. The data were remapped onto the CMAQ grid, and relevant variables were extracted and converted using a modified version of CMAQ's Meteorology-Chemistry Interface Processor (MCIP) (Otte and Pleim, 2010).
The European land-based emissions were compiled with SMOKE for Europe (Bieser et al., 2011), and agricultural emissions were updated according to Backes et al. (2016a, b). Shipping emissions were calculated on the basis of $\mathrm{Au}-$ tomated Identification System (AIS) data (Aulinger et al., 2016). Sea salt emissions were calculated inline (Kelly et al., 2010; Gong, 2003) and scaled by annual average salinity. Details on the sea salt emissions are given in the next section. The salinity data were taken from runs of a hydrodynamic model based on HAMSOM (HAMburg Shelf Ocean Model). A detailed description of the hydrodynamic model and recent updates were published by Schrum and Backhaus (1999) and Barthel et al. (2012), respectively.

\subsection{Sea salt emissions}

Physically, sea salt particles are dried sea water droplets that are ejected from the sea surface into the atmosphere (Lewis and Schwartz, 2004). Under most weather conditions, the generation of sea salt particles is dominated by bubble bursting: air is mixed into sea water by breaking waves and forms air bubbles that rise to the sea surface and burst. Small water droplets are ejected from the breaking hull of the bubble (film droplets). Through the abruptly changing pressure within the bursting bubble, some water is sucked from below the bubble into the air (jet droplets). The fraction of sea surface covered by bursting bubbles is denoted as white cap coverage. Droplets, which are emitted primarily when waves break and are torn by the wind from wave crests, are termed splash and spume droplets, respectively. High wind speeds of larger than approximately $10 \mathrm{~m} \mathrm{~s}^{-1}$ are needed for both processes to be relevant for atmospheric sea salt particle generation. The naming conventions for spume and splash droplets are not consistent throughout the literature.

The amount of sea salt per droplet and the resulting sea salt particle size are governed by the sea surface salinity (Martensson et al., 2003). Sea surface temperature, biofilms, and other surfactants affect the sea salt particle size spectra (Martensson et al., 2003; Gantt et al., 2011). In the surf zone, sea salt emissions are enhanced due to a higher number of breaking waves. Additionally, sea salt particles may be electrically charged (Gathman and Hoppel, 1970; Bowyer et al., 1990).

\subsubsection{Sea salt emission parameterizations in CMAQ}

Edward Monahan and colleagues (Monahan et al., 1982; Monahan and Muircheartaigh, 1980) derived a parameterization that describes the generation of sea salt particles by bursting bubbles. A sea salt particle number flux distribution was estimated for $100 \%$ white cap coverage and multiplied by the white cap coverage $W$, which is fitted by a power law to the $10 \mathrm{~m}$ wind speed $\left(u_{10}\right)$ as given in Eq. (1) (Monahan et al., 1986, Eq. 12). Sea salt emissions in CMAQ are calculated following Gong (2003), an enhancement of Monahan 
et al. (1982) that incorporates smaller radii (see Eq. 2). Particle number, dry surface, dry mass flux, and water content at an ambient relative humidity (RH) are calculated explicitly in CMAQ. Water content is calculated using a polynomial fit published by Zhang et al. (2005). The total emitted dry sea salt mass is split into $7.55 \% \mathrm{SO}_{4}^{2-}, 53.98 \% \mathrm{Cl}^{-}$, and $38.56 \% \mathrm{Na}^{+}$(Kelly et al., 2010). The model $\mathrm{Na}^{+}$represents $\mathrm{Na}^{+}, \mathrm{Mg}^{2+}, \mathrm{K}^{+}$, and $\mathrm{Ca}^{2+}$.

$$
\begin{aligned}
& W=3.84 \times 10^{-6} \times u_{10}^{3.41} \\
& \frac{\mathrm{d} F}{\mathrm{~d} r_{80}}=W \times 3.5755 \times 10^{5} \times r_{80}^{-A} \times\left(1+0.057 \times r_{80}^{3.45}\right) \\
& \times 10^{1.607 \times e^{-B^{2}}} \\
& =1.373 \times u_{10}^{3.41} \times r_{80}^{-A} \times\left(1+0.057 \times r_{80}^{3.45}\right) \\
& \times 10^{1.607 \times e^{-B^{2}}} \\
& A=4.7 \times\left(1+\theta \times r_{80}\right)^{-0.017 \times r_{80}^{-1.44}} \\
& B=\frac{0.433-\log \left(r_{80}\right)}{0.433}
\end{aligned}
$$

In the above equations, $r_{80}(\mu \mathrm{m})$ is the particle radius at $80 \%$ $\mathrm{RH}, u_{10}\left(\mathrm{~m} \mathrm{~s}^{-1}\right)$ is the $10 \mathrm{~m}$ wind speed and $\theta$ is an adjustable parameter, which is set to 30 . The term $\mathrm{d} F / \mathrm{d} r$ is the number flux (number $\mathrm{m}^{-2} \mu \mathrm{m}^{-1} \mathrm{~s}^{-1}$ ) of sea salt particles. The parameterization is valid in a size range of $0.06 \mu \mathrm{m} \leq r_{80} \leq 20 \mu \mathrm{m}$.

\subsubsection{Surf zone emissions}

In the surf zone, the sea salt particle number flux is considerably higher than in the open ocean. Addressing surf zone emissions is quite difficult because they depend on the direction of waves and the wind, as well as on local coastal features, such as steep cliffs and flat beaches. In the employed CMAQ version, the surf zone is parameterized by setting the white cap coverage $W$ to 1 . The surf zone area is proposed to be a $50 \mathrm{~m}$ wide strip along the coastline (Kelly et al., 2010). CMAQ simulations in parts of Florida performed well with this definition of surf zone (J. T. Kelly, personal communication, 2014). Equation (3) shows a modified emission function in cooperating surf zone and open ocean fractions. These fractions need to be pre-calculated for each model domain.

$$
\frac{\mathrm{d} F_{\text {eff }}}{\mathrm{d} r_{80}}=(W \times \text { open }+ \text { surf }) \times \frac{1}{W} \times \frac{\mathrm{d} F}{\mathrm{~d} r_{80}}
$$

For this study, the ratios of open ocean and surf zone surface per grid cell were calculated by ArcGIS based on the Natural Earth data set. The surf zone area was obtained by placing a $50 \mathrm{~m}$ wide strip along the coastline and calculating the area of that strip. Overlapping areas were ignored. Grid cells with long fragmented coastlines and many islands do not necessarily have a large surf zone area because some parts of the coastline and islands are protected by others. Therefore, the surf zone fraction per grid cell was cut at a threshold (see Supplement for details).

\subsubsection{Salinity dependence}

The salinity in large parts of the Baltic Sea is less than $10 \%$, in contrast to the North Sea value of $35 \%$. Therefore, the sea salt emissions must be corrected to account for differences in salinity. The open ocean and surf zone coverage data were scaled by the salinity $S(S / 0.035$, with $0.035=35 \%$ o $)$ to obtain salinity-dependent sea salt emissions (Martensson et al., 2003). CMAQ sea salt emissions would otherwise not depend on salinity. Sea ice cover is not considered. Finally, Eq. (4) for sea salt emissions was obtained:

$$
\frac{\mathrm{d} F_{\text {eff }}}{\mathrm{d} r_{80}}=\frac{S}{0.035} \times(W \times \text { open }+ \text { surf }) \times \frac{1}{W} \times \frac{\mathrm{d} F}{\mathrm{~d} r_{80}} .
$$

The technical procedure of including salinity dependence is described in the Supplement Sect. A and references to the modeled salinity are given in Sect. 2.3. Annual average salinity data from the year 1993 were used. Annual averages were taken because the oceanic data are time independent in CMAQ. In the central, eastern, and northern parts of the Baltic Sea, the seasonal variability of the salinity is low on the scales relevant for sea salt emissions. In contrast, in the Kattegat the seasonal variation can be up to $\pm 10 \%$ o with respect to the annual average.

Unfortunately, data for the year 2008 were not available to the authors when the CMAQ model runs were performed. According to Matthäus et al. (1997) and Nausch et al. (2009), the difference in the sea surface salinity between the years 1993 and 2008 is low. The interannual and seasonal affects on the sea salt emissions are low compared to the difference between salinity-scaled and non-salinity-scaled sea salt emissions (for example, see Fig. S4 in the Supplement). Therefore, we assume that employing salinity data from the year 1993 instead of 2008 has no relevant impact on the results of this study.

\subsubsection{Sea salt emission scenarios}

Four different sea salt emission cases are investigated in this study: base, noSurf, zero, and full. The base case corresponds to the standard CMAQ sea salt emissions extended by the salinity scaling described in Sect. 2.4.3. The zero case contains no sea salt emissions. In the noSurf case, the surf zone is treated as the open ocean. In the full case, the standard CMAQ sea salt emissions without any extensions are used (no salinity scaling). The cases are listed in Table 1.

\subsection{Evaluation procedure}

The CMAQ simulation results were evaluated against concentration measurements performed at EMEP stations. The data were obtained via EBAS (http://ebas.nilu.no/). The stations were chosen according to the availability of data for comparison (Fig. 2). Three stations - Westerland (DE0001R), Waldhof (DE0002R), and Zingst (DE0009R) - 
Table 1. Sea salt emission cases.

\begin{tabular}{|c|c|}
\hline Case & Description \\
\hline Base & $\begin{array}{l}\text { Standard CMAQ sea salt emissions but scaled by } \\
\text { salinity: } 50 \mathrm{~m} \text { surf zone, coast line from } \\
\text { Natural Earth data set, linearly scaled with } \\
\text { salinity }\end{array}$ \\
\hline NoSurf & Like base but surf zone is treated like open ocean \\
\hline Zero & No sea salt \\
\hline Full & $\begin{array}{l}\text { Standard CMAQ sea salt emissions (like base case but } \\
\text { no salinity scaling) }\end{array}$ \\
\hline
\end{tabular}

are described in detail in Sect. 3; the data from the other stations are evaluated only statistically and the original data are included in the Supplement. The Westerland station is located directly on the North Sea coast, Zingst is located on the Baltic Sea coast, and Waldhof is located approximately $200 \mathrm{~km}$ inland. Thus, these stations' measurements cover three different sea salt emission regimes. All stations are divided into coastal (within $50 \mathrm{~km}$ downwind to the coast) and inland stations.

Species including $\mathrm{Na}^{+}, \mathrm{NH}_{3}+\mathrm{NH}_{4}^{+}$, and $\mathrm{HNO}_{3}+\mathrm{NO}_{3}^{-}$ were compared. Sea salt emissions are the major source of atmospheric sodium cations $\left(\mathrm{Na}^{+}\right)$. Na ${ }^{+}$does not evaporate from sea salt particles in contrast to $\mathrm{Cl}^{-}$and it does not condense onto particles in contrast to $\mathrm{HCl}$ and $\mathrm{H}_{2} \mathrm{SO}_{4}$. Therefore, $\mathrm{Na}^{+}$is a good tracer for sea salt particles and is considered for evaluating sea salt particle predictions. Ammonium $\left(\mathrm{NH}_{4}^{+}\right)$and ammonia $\left(\mathrm{NH}_{3}\right)$ as well as nitrate $\left(\mathrm{NO}_{3}^{-}\right)$ and nitric acid $\left(\mathrm{HNO}_{3}\right)$ are considered as sums only. Because these substances were collected with three-stage filter packs at most of the considered EMEP stations in 2008, the individual measurements of $\mathrm{NH}_{4}^{+}, \mathrm{NH}_{3}, \mathrm{NO}_{3}^{-}$, and $\mathrm{HNO}_{3}$ are subject to large uncertainties, whereas the sums are accurately determined (EMEP, 2014, Chp. 3).

Daily mean concentrations are compared as plotted time series and box plots and via three statistical metrics (Eqs. A1, $\mathrm{A} 2$, and $\mathrm{A} 3$ ): residual absolute error (RAE), mean normalized bias (MNB), and Spearman's correlation coefficient $(R)$. See Schlünzen and Sokhi (2008) for descriptions of these figures. The box plots contain data from only those days for which measurement data are available.

Nitrogen deposition is considered in Sect. 3.3. It is calculated according to Eqs. (B1) to (B3). The nitrogen wet deposition is compared to measurement data at most of the stations in Fig. 2 (where available) via $R$ and the mean values ( $\mu_{\text {sim }}$ and $\left.\mu_{\mathrm{obs}}\right) . R$ was only calculated when more than ten measurements were available. Measured rain water concentrations were converted into nitrogen deposition per area by the measured amount of rain water. No validation of total nitrogen deposition (wet + dry) against measurement data is performed due to the lack of dry deposition measurement data.

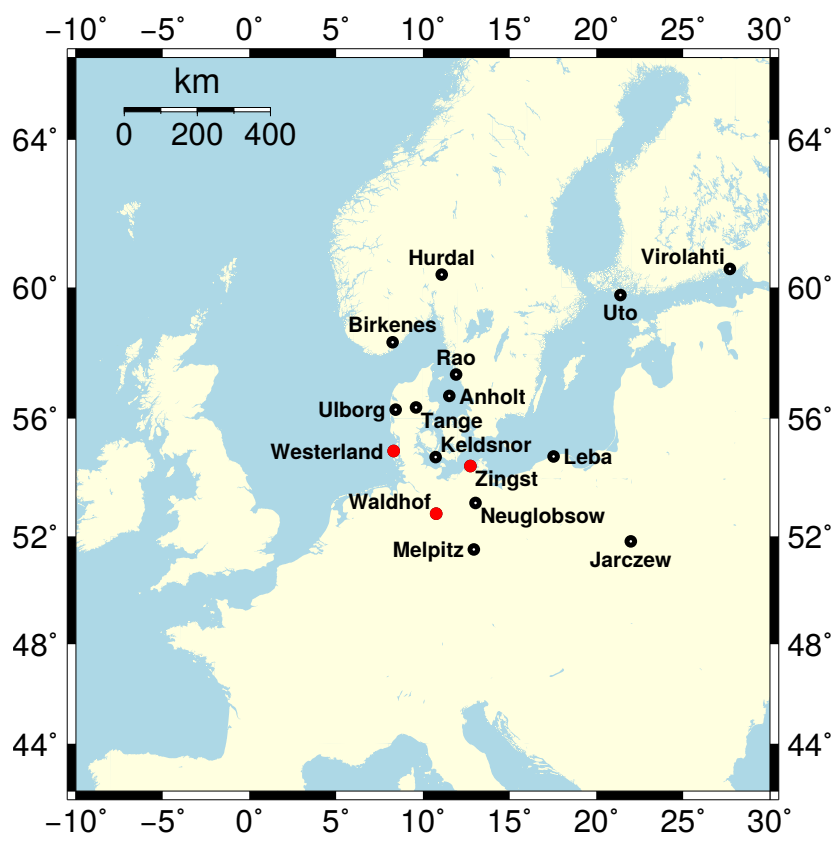

Figure 2. The EMEP stations chosen for the comparison to the CMAQ data. Red circles indicate the station data, which are plotted in Sect. 3.

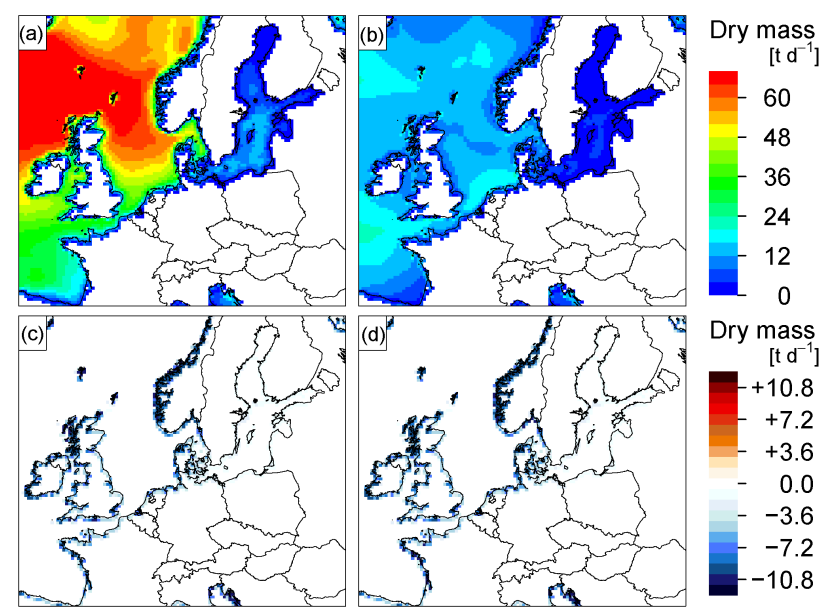

Figure 3. Average total sea salt emissions in $t / d$ of the base case (top row) in winter 2008 (a) and summer 2008 (b). The difference to the noSurf case (noSurf - base) is shown in the bottom row (c, d).

\section{Results}

\subsection{Emissions}

Figure 3 shows modeled monthly averaged sea salt emissions for the base emission case (top row) in winter and summer (left and right columns, respectively). The bottom row shows the differences between the noSurf and base cases. 


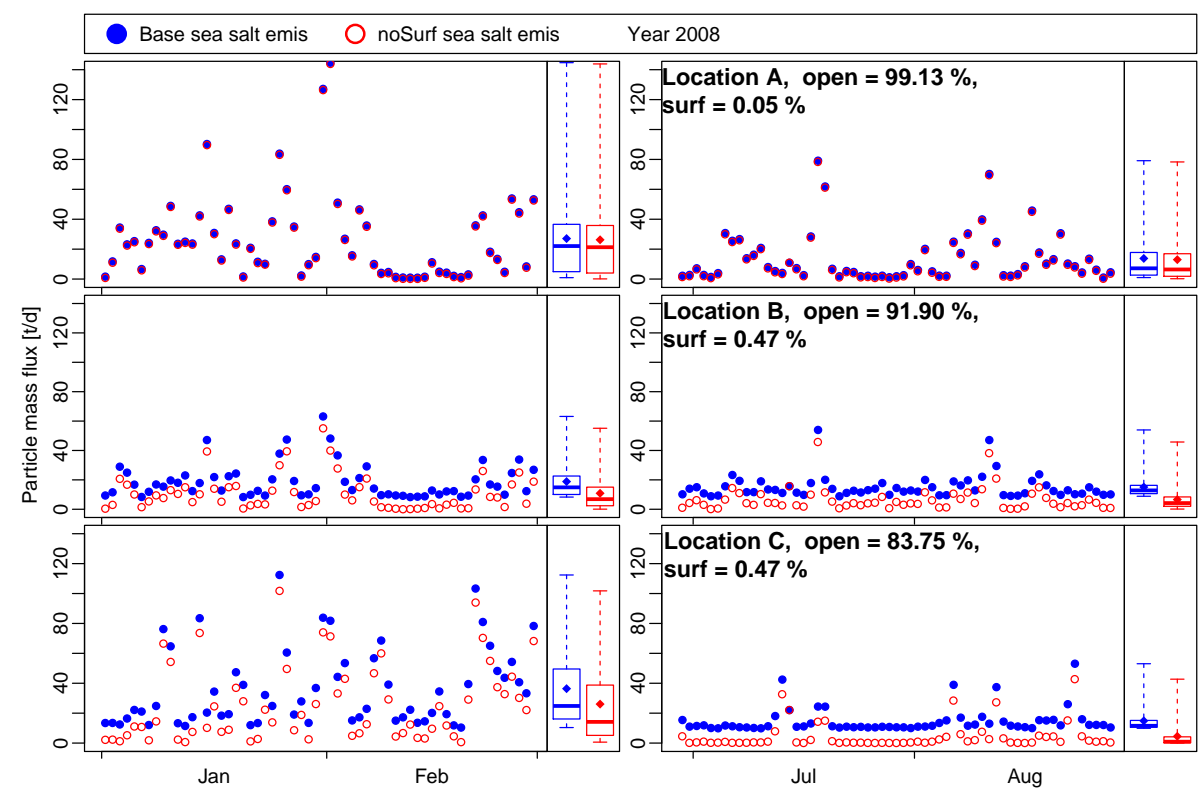

Figure 4. Daily averaged sea salt emission flux in $t / d$ in three example coastal grid cells (one per row) in winter 2008 (left) and summer 2008 (right). The fraction of open ocean and surf zone is listed in the plots on the right. The remaining share is land. Location A is located on the Dutch coast, location B is on the German coast, and location C is on the Norwegian Atlantic coast.

According to Fig. 3, winter sea salt emissions are 2 to 5 times higher than summer sea salt emissions due to higher wind speeds. In the Baltic Sea, sea salt emissions are considerably lower than in the North Sea, which is caused by the salinity-dependent downscaling of the sea salt emissions. Because wind speeds decrease towards the coast and are highest above open waters, sea salt emissions decrease towards the coast as well. Comparing the base and noSurf sea salt emissions, the greatest differences are observed along the Norwegian and British Atlantic coasts, and lowest differences are observed along the Baltic Sea coast.

Figure 4 shows daily averaged sea salt emissions in three coastal grid cells. Although the surf zone covers only a small fraction of the grid cell surface, surf zone emissions contribute a considerable share of sea salt emissions in low wind speed situations. This result emphasizes the importance of correctly parameterizing surf zone sea salt emissions.

\subsection{Concentrations}

The modeled and measured concentrations of two 60-day time series (summer and winter) at 16 EMEP stations are analyzed in this section based on key statistical figures. Three of these EMEP stations, i.e., Westerland (DE0001R), Waldhof (DE0002R), and Zingst (DE0009R), are described and discussed in more detail by considering the actual time series and box plots of the data. For the box plots, only the modeling data points that had corresponding measurement data points were used. The corresponding raw data from the stations are attached as Supplement.

\subsubsection{Sodium}

The concentration time series in Fig. 5 shows that the dates of peaks are consistent across all three stations. The correlation coefficient is greater than 0.75 in winter and greater than 0.70 in summer. However, the magnitudes of the peak values do differ in most situations. The model overestimates these values. During winter, overestimations of peak concentrations occur at all stations, which is indicated by the box plots (Fig. 5) and the bias values (Table 2). Coastal and inland station cannot be distinguished via the MNB during winter, but the RAE is higher at coastal stations than at inland ones. The correlation coefficient is nearly 0.6 or above at all stations except at Ulborg, Keldsnor, and Virolahti II. During summer, sea salt is moderately overestimated at coastal stations (Westerland and Zingst) and underestimated inland (Waldhof), as indicated by the plots and bias values. The MNBs of the other stations, except those of Tange and Keldsnor, support this finding. The measured base line concentrations, i.e., when no peaks are present, are well matched by the model. Winter sodium concentrations are approximately twice as high as summer concentrations (see scale in Fig. 5). The RAE and the MNB values are lower at most stations during summer than during winter, whereas $R$ does not show any tendency between the two seasons.

Deactivating surf zone emissions leads to a reduction in the modeled concentrations most of the time. MNB is reduced at all stations. This reduction leads to a lower bias in situations when concentrations are overestimated in the base case. However, the concentrations are further underestimated 


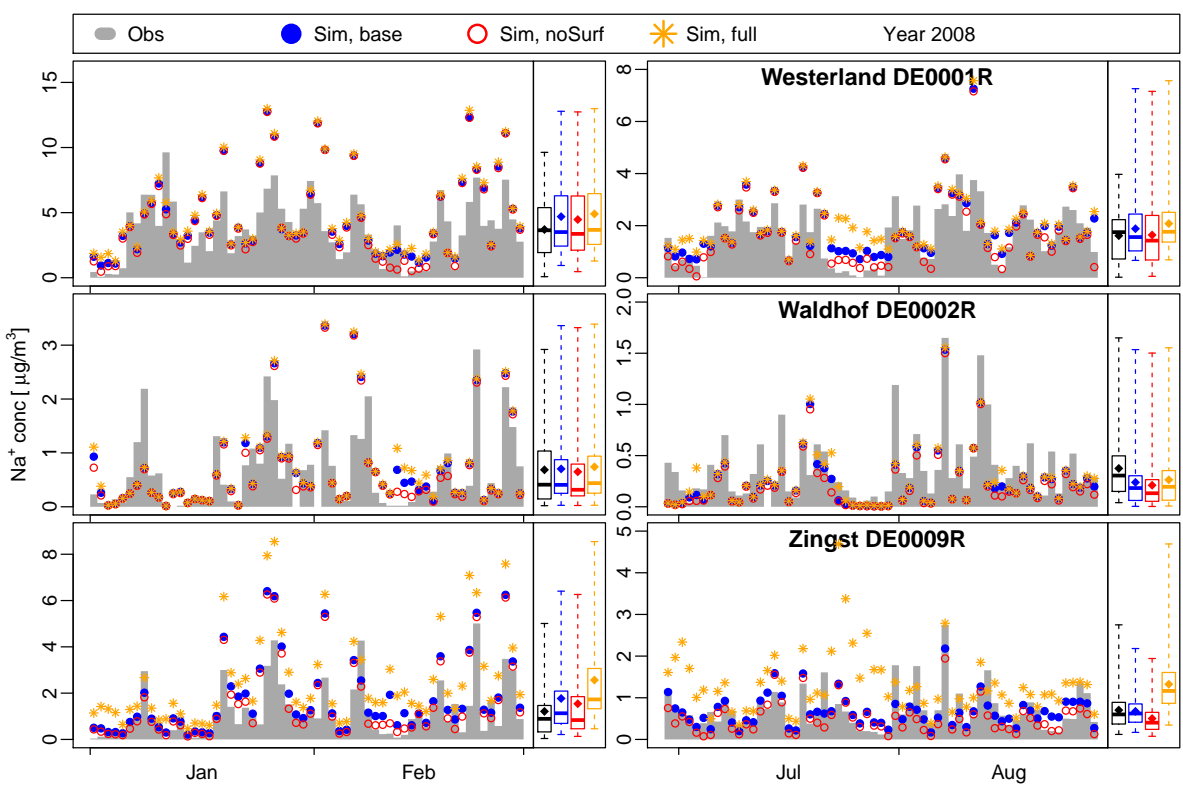

Figure 5. Measured (gray bars and black box plots) and modeled (colored symbols) sodium concentrations at three stations (top to bottom) during winter 2007/08 (left) and summer 2008 (right). The orange line indicates sodium concentrations without salinity-dependent downscaling of sea salt emissions. On the left of each plot, the time series of the data are plotted. To the right of each time series, box plots showing the minimum, $25 \%$ percentile, median, $75 \%$ percentile, maximum, and mean values (rhombus) are shown.

in situations when concentrations are already underestimated in the base case. Surf zone emissions lead to a slight improvement in $R$ and the RAE. No clear differences between the effects of summer and winter are visible through deactivating surf zone emissions. Surf zone emissions have an important impact in certain low-emission periods, such as in midFebruary and at the end of July, when surf zone emissions contribute more than the half of the atmospheric sodium.

The zero case is not considered here. The orange asterisks represent a simulation without salinity-dependent scaling of sea salt emissions denoted as the full case. The simulation considerably overestimated sodium concentrations at Zingst (Baltic Sea coast). At all coastal stations, the full case leads to higher MNB values than the base case. The impacts on the two Finish stations Utö and Virolahti II on the eastern Baltic Sea coast are particularly strong. Salinity scaling of emissions is therefore important. Because sodium concentrations are not underestimated at Zingst and not as overestimated as in the non-salinity-scaling case, we assume that the applied linear salinity scaling of the sea salt emissions in the Baltic Sea is a valid procedure as a first-order correction.

\subsubsection{Ammonia and ammonium}

$\mathrm{NH}_{3}+\mathrm{NH}_{4}^{+}\left(\mathrm{sNH}_{4}, \mathrm{~s}=\right.$ sum $)$ concentrations are slightly underestimated at Westerland, as shown in the time series (Fig. 6) and indicated by the box plots and the MNB (Table 3). During summer, the absolute MNB value is high, but the correlation is strong, which can also be observed directly in the time series in Fig. 6: the shape is well matched, but the predicted magnitude is generally too low. In winter, certain peak concentrations are overestimated, which improves the MNB and RAE values but decreases $R$. At Waldhof, baseline concentrations are well matched, but peak concentrations are overestimated. In winter, the MNB is lower than during summer due to a strongly underestimated time period at the end of February. The correlation coefficient is 0.59 in winter and increases slightly in summer to 0.63 . At Zingst, the measured concentrations are most consistent in terms of the order of magnitude, which is represented by MNB $\approx 0$ and by a low RAE. The occurrence of peaks is well matched, but the correlation coefficient is less than 0.5 in summer. This pattern is caused by peak concentrations that are sometimes over- and sometimes underestimated. For example, in late July, CMAQ predicts a decrease in concentrations, but measured concentrations increase. This episode will be analyzed in more detail in Sect. 4.3. At most of the 16 stations, the correlation is better and the RAE is worse in winter compared to summer.

The effect of surf zone sea salt emissions on $\mathrm{SNH}_{4}$ is negligible, as indicated by the plots and statistics. During winter, zero case $\mathrm{sNH}_{4}$ concentrations increase slightly, particularly when peak concentrations occur. Because these peak concentrations are already overestimated in the base case, deactivating sea salt emissions does not improve the predictions. The impact of deactivating sea salt emissions on the MNB, the RAE and $R$ values is low and no clear increase or decrease of the MNB or $R$ are induced. The RAE rather decreases at coastal stations and rather increases at inland stations. 
Table 2. Statistical values (RAE, MNB, and $R$ ) for the comparison of measured and modeled (base and noSurf scenarios) sodium concentrations at all considered stations (Fig. 2) and during two time periods (winter and summer 2008).

\begin{tabular}{|c|c|c|c|c|c|c|c|c|c|}
\hline \multirow{2}{*}{$\begin{array}{l}\mathrm{Na}^{+} \\
\text {Station }\end{array}$} & \multirow[b]{2}{*}{ Case } & \multicolumn{4}{|c|}{ Winter 2008} & \multicolumn{4}{|c|}{ Summer 2008} \\
\hline & & $n$ & RAE & MNB & $R$ & $n$ & RAE & MNB & $R$ \\
\hline Westerland & base & 60 & 1.89 & 1.01 & 0.76 & 61 & 0.72 & 2.37 & 0.70 \\
\hline DE0001R & noSurf & 60 & 1.84 & 0.65 & 0.75 & 61 & 0.63 & 1.17 & 0.79 \\
\hline Coast & full & 60 & 2.01 & 1.31 & 0.75 & 61 & 0.87 & 3.51 & 0.49 \\
\hline Waldhof & base & 55 & 0.42 & 1.75 & 0.67 & 60 & 0.18 & -0.33 & 0.70 \\
\hline DE0002R & noSurf & 55 & 0.40 & 1.02 & 0.74 & 60 & 0.20 & -0.43 & 0.71 \\
\hline Inland & full & 55 & 0.45 & 2.51 & 0.63 & 60 & 0.18 & -0.21 & 0.65 \\
\hline Neuglobsow & base & 60 & 0.30 & 1.27 & 0.76 & 59 & 0.18 & -0.36 & 0.71 \\
\hline DE0007R & noSurf & 60 & 0.29 & 0.66 & 0.81 & 59 & 0.19 & -0.47 & 0.73 \\
\hline Inland & full & 60 & 0.35 & 2.40 & 0.69 & 59 & 0.17 & -0.16 & 0.68 \\
\hline Zingst & base & 60 & 0.72 & 1.24 & 0.79 & 61 & 0.26 & 0.20 & 0.69 \\
\hline DE0009R & noSurf & 60 & 0.64 & 0.69 & 0.82 & 61 & 0.31 & -0.16 & 0.62 \\
\hline Coast & full & 60 & 1.40 & 3.28 & 0.69 & 61 & 0.70 & 1.75 & 0.36 \\
\hline Melpitz & base & 59 & 0.25 & 0.43 & 0.66 & 61 & 0.11 & -0.35 & 0.69 \\
\hline DE0044R & noSurf & 59 & 0.25 & 0.32 & 0.67 & 61 & 0.12 & -0.43 & 0.70 \\
\hline Inland & full & 59 & 0.25 & 0.54 & 0.66 & 61 & 0.11 & -0.24 & 0.65 \\
\hline Tange & base & 56 & 1.03 & 1.12 & 0.67 & 61 & 0.44 & 0.88 & 0.65 \\
\hline DK0003R & noSurf & 56 & 0.96 & 0.56 & 0.74 & 61 & 0.41 & 0.02 & 0.74 \\
\hline Inland & full & 56 & 1.11 & 1.37 & 0.60 & 61 & 0.50 & 1.50 & 0.46 \\
\hline Keldsnor & base & 60 & 1.26 & 0.75 & 0.48 & 56 & 0.46 & 0.21 & 0.26 \\
\hline DK0005R & noSurf & 60 & 1.07 & 0.11 & 0.65 & 56 & 0.50 & -0.32 & 0.53 \\
\hline Coast & full & 60 & 1.64 & 1.47 & 0.39 & 56 & 0.85 & 1.03 & 0.09 \\
\hline Anholt & base & 59 & 1.26 & 0.51 & 0.81 & 51 & 0.60 & 0.05 & 0.69 \\
\hline DK0008R & noSurf & 59 & 1.19 & 0.32 & 0.82 & 51 & 0.67 & -0.23 & 0.70 \\
\hline Coast & full & 59 & 1.61 & 0.75 & 0.77 & 51 & 0.62 & 0.36 & 0.66 \\
\hline Ulborg & base & 60 & 1.41 & 1.63 & 0.77 & 54 & 0.68 & 1.22 & 0.52 \\
\hline DK0031R & noSurf & 60 & 1.22 & 0.38 & 0.85 & 54 & 0.48 & -0.03 & 0.76 \\
\hline Coast & full & 60 & 1.48 & 1.83 & 0.75 & 54 & 0.75 & 1.66 & 0.48 \\
\hline Utö & base & 59 & 0.59 & 1.26 & 0.59 & 61 & 0.24 & 0.24 & 0.67 \\
\hline FI0009R & noSurf & 59 & 0.52 & 0.92 & 0.62 & 61 & 0.26 & -0.29 & 0.74 \\
\hline Coast & full & 59 & 3.16 & 6.09 & 0.57 & 61 & 0.99 & 4.79 & 0.41 \\
\hline Virolahti II & base & 60 & 0.24 & 1.50 & 0.37 & 60 & 0.12 & 0.07 & 0.74 \\
\hline FI0017R & noSurf & 60 & 0.21 & 1.05 & 0.42 & 60 & 0.14 & -0.16 & 0.70 \\
\hline Coast & full & 60 & 1.01 & 6.27 & 0.23 & 60 & 0.34 & 2.61 & 0.73 \\
\hline Birkenes & base & 60 & 0.89 & 5.77 & 0.57 & 61 & 0.26 & 1.12 & 0.35 \\
\hline NO0001R & noSurf & 60 & 0.81 & 4.31 & 0.58 & 61 & 0.23 & -0.14 & 0.60 \\
\hline Mixed & full & 60 & 0.92 & 6.13 & 0.57 & 61 & 0.27 & 1.34 & 0.29 \\
\hline Hurdal & base & 59 & 0.49 & 3.80 & 0.30 & 55 & 0.10 & 0.23 & 0.51 \\
\hline NO0056R & noSurf & 59 & 0.42 & 2.80 & 0.42 & 55 & 0.10 & -0.22 & 0.51 \\
\hline Inland & Inland & 59 & 0.52 & 4.17 & 0.28 & 55 & 0.10 & 0.56 & 0.43 \\
\hline
\end{tabular}

\subsubsection{Nitrate and nitric acid}

At Westerland, several measured $\mathrm{sNO}_{3}$ concentrations in the EMEP database are marked as "under detection limit", which leaves only 21 comparable values in winter and 26 in sum- mer. In mid-February, very high concentrations are predicted, even though the measured values were below the detection limit. Due to the low number of valid measurements, Westerland was not analyzed further. 


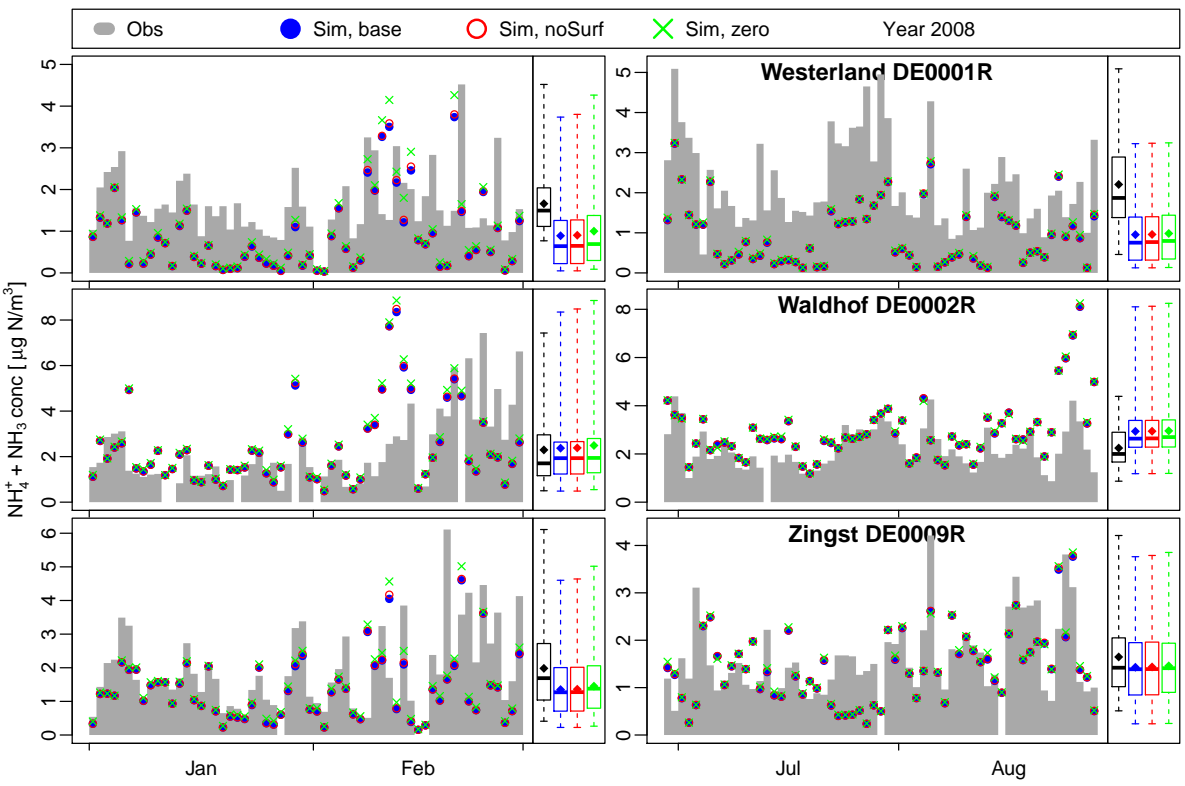

Figure 6. Similar to Fig. 5 but showing $\mathrm{sNH}_{4}$ values of the base, noSurf, and zero sea salt emission cases.

At Waldhof, the average concentrations are well represented, as indicated by box plots (Fig. 7) and MNB (Table 4). In winter, the timing of peaks is well matched, but their heights are overestimated in some situations and underestimated in others. This leads to a high RAE value of approximately 0.7. Additionally, in mid-February, one wide and high peak is considerably overestimated. In summer, the RAE improves. However, the correlation coefficient decreases from 0.64 to 0.34 due to two quite poorly matched peaks at the beginning and end of August. The winter concentrations at Zingst are very well represented by CMAQ. The time series plots and box plots agree with each other, yielding an $R$ value of 0.76 . In summer, the correlation decreases. A period of highly underestimated $\mathrm{sNO}_{3}$ concentrations exists in late July at Zingst and Waldhof. Comparing all the stations, $R$ and the RAE are higher in winter meaning that the correlation improves but the error worsens from summer to winter. During winter, the $\mathrm{SNO}_{3}$ concentrations are underestimated at several stations, as indicated by negative MNBs. In summer, the MNBs are positive at all stations.

In the no surf zone case, $\mathrm{sNO}_{3}$ concentrations are slightly higher than those of the base case (higher MNB) but $R$ does not change by more \pm 0.01 . Deactivating sea salt emissions increases predicted $\mathrm{sNO}_{3}$ concentrations at most stations as indicated by the higher MNB values. The RAE and $R$ values show no tendency. The prediction quality, i.e., $R$ and MNB, increases at Waldhof and Zingst because slightly underestimated concentrations are increased, which automatically improves MNB.

Because $\mathrm{sNO}_{3}$ concentrations do not necessarily represent $\mathrm{NO}_{3}^{-}$concentrations, Fig. 8 shows the $\mathrm{NO}_{3}^{-}$concentrations at the three known stations, and Table 5 shows the bias of the zero case $\mathrm{NO}_{3}^{-}$and $\mathrm{sNO}_{3}$ concentrations with respect to the base case concentrations. Usable measurement data were only available for Melpitz. Therefore, no comparison to measurement data is performed here.

The MNB for $\mathrm{NO}_{3}^{-}$concentrations is negative with a few exceptions. Thus, nitrate concentrations are commonly higher in the presence of sea salt. The exceptions are inland stations at which positive MNBs occur. In contrast, the MNB values for $\mathrm{sNO}_{3}$ concentrations are positive at all stations throughout the year which indicates the increase in $\mathrm{sNH}_{3}$ concentrations in the absence of sea salt, as noted above.

\subsection{Nitrogen deposition}

Figure $9 \mathrm{a}$ and $\mathrm{b}$ show the nitrogen deposition in the base case during winter and summer, respectively. In most regions, nitrogen deposition is higher during summer than during winter - up to twice as high and in some regions even higher. During winter, the deposition is highest in western France, the Netherlands, Belgium, northwestern Germany, and northern Italy (Po Valley). During summer, the greatest deposition occurs in the same regions and, additionally, above the northern part of the Alps. The Po Valley deposition is on the same order of magnitude during both seasons, but the deposition in the other regions exhibits the described seasonal pattern.

The nitrogen deposition difference between the noSurf and the base case (Fig. 9c and d, noSurf - base) shows that deactivating surf zone emissions leads to a strong reduction in the nitrogen deposition along the coast line of the southern North Sea and the western Baltic Sea. The nitrogen deposition is slightly increased far from the coast in inland regions and above the ocean. The differences are higher in summer 
Table 3. Similar to Table 2 but showing $\mathrm{sNH}_{4}\left(\mathrm{NH}_{3}+\mathrm{NH}_{4}^{+}\right)$concentrations. Three sea salt emissions scenarios - base, noSurf, and zero are considered.

\begin{tabular}{|c|c|c|c|c|c|c|c|c|c|}
\hline \multirow{2}{*}{$\begin{array}{l}\mathrm{sNH}_{4} \\
\text { Station }\end{array}$} & \multirow[b]{2}{*}{ Case } & \multicolumn{4}{|c|}{ Winter 2008} & \multicolumn{4}{|c|}{ Summer 2008} \\
\hline & & $n$ & RAE & MNB & $R$ & $n$ & RAE & MNB & $R$ \\
\hline Westerland & base & 58 & 1.00 & -0.46 & 0.60 & 61 & 1.29 & -0.57 & 0.69 \\
\hline DE0001R & noSurf & 58 & 0.99 & -0.45 & 0.61 & 61 & 1.29 & -0.56 & 0.69 \\
\hline Coast & zero & 58 & 0.96 & -0.39 & 0.60 & 61 & 1.27 & -0.55 & 0.69 \\
\hline Waldhof & base & 54 & 1.28 & 0.25 & 0.59 & 60 & 0.88 & 0.39 & 0.63 \\
\hline DE0002R & noSurf & 54 & 1.28 & 0.26 & 0.59 & 60 & 0.88 & 0.39 & 0.63 \\
\hline Inland & zero & 54 & 1.31 & 0.31 & 0.59 & 60 & 0.89 & 0.40 & 0.62 \\
\hline Neuglobsow & base & 57 & 1.01 & 0.21 & 0.63 & 59 & 0.93 & 0.68 & 0.36 \\
\hline DE0007R & noSurf & 57 & 1.01 & 0.22 & 0.63 & 59 & 0.93 & 0.68 & 0.36 \\
\hline Inland & zero & 57 & 1.04 & 0.28 & 0.64 & 59 & 0.94 & 0.69 & 0.35 \\
\hline Zingst & base & 57 & 0.81 & -0.19 & 0.72 & 59 & 0.60 & -0.02 & 0.46 \\
\hline DE0009R & noSurf & 57 & 0.81 & -0.19 & 0.72 & 59 & 0.60 & -0.01 & 0.46 \\
\hline Coast & zero & 57 & 0.77 & -0.12 & 0.71 & 59 & 0.60 & 0.00 & 0.47 \\
\hline Tange & base & 60 & 1.23 & 3.84 & 0.56 & 55 & 1.28 & 0.72 & 0.40 \\
\hline DK0003R & noSurf & 60 & 1.24 & 3.86 & 0.56 & 55 & 1.29 & 0.73 & 0.41 \\
\hline Inland & zero & 60 & 1.31 & 4.13 & 0.57 & 55 & 1.32 & 0.75 & 0.40 \\
\hline Keldsnor & base & 59 & 0.71 & 0.01 & 0.66 & 55 & 0.70 & 0.17 & 0.38 \\
\hline DK0005R & noSurf & 59 & 0.71 & 0.02 & 0.66 & 55 & 0.71 & 0.18 & 0.38 \\
\hline Coast & zero & 59 & 0.70 & 0.09 & 0.65 & 55 & 0.71 & 0.20 & 0.37 \\
\hline Anholt & base & 59 & 0.40 & -0.06 & 0.78 & 51 & 0.24 & 0.38 & 0.67 \\
\hline DK0008R & noSurf & 59 & 0.41 & -0.05 & 0.78 & 51 & 0.24 & 0.39 & 0.67 \\
\hline Coast & zero & 59 & 0.41 & 0.07 & 0.78 & 51 & 0.26 & 0.44 & 0.66 \\
\hline Ulborg & base & 60 & 0.48 & 0.08 & 0.79 & 55 & 0.68 & 0.51 & 0.80 \\
\hline DK0031R & noSurf & 60 & 0.49 & 0.09 & 0.79 & 55 & 0.68 & 0.52 & 0.79 \\
\hline Coast & zero & 60 & 0.53 & 0.21 & 0.78 & 55 & 0.70 & 0.56 & 0.79 \\
\hline Utö & base & 59 & 0.32 & 0.93 & 0.81 & 61 & 0.13 & 0.08 & 0.57 \\
\hline FI0009R & noSurf & 59 & 0.32 & 0.95 & 0.81 & 61 & 0.13 & 0.08 & 0.57 \\
\hline Coast & zero & 59 & 0.33 & 1.25 & 0.82 & 61 & 0.14 & 0.12 & 0.55 \\
\hline Virolahti II & base & 60 & 0.39 & 2.00 & 0.75 & 60 & 0.18 & 0.54 & 0.64 \\
\hline FI0017R & noSurf & 60 & 0.39 & 2.03 & 0.74 & 60 & 0.18 & 0.54 & 0.64 \\
\hline Coast & zero & 60 & 0.43 & 2.32 & 0.75 & 60 & 0.19 & 0.57 & 0.64 \\
\hline Birkenes & base & 51 & 0.22 & 1.11 & 0.52 & 53 & 0.25 & 0.02 & 0.40 \\
\hline NO0001R & noSurf & 51 & 0.23 & 1.14 & 0.52 & 53 & 0.25 & 0.04 & 0.40 \\
\hline Mixed & zero & 51 & 0.28 & 1.61 & 0.50 & 53 & 0.26 & 0.10 & 0.36 \\
\hline Hurdal & base & 53 & 0.72 & 3.71 & 0.19 & 58 & 0.17 & 0.24 & 0.31 \\
\hline NO0056R & noSurf & 53 & 0.73 & 3.78 & 0.18 & 58 & 0.18 & 0.25 & 0.31 \\
\hline Inland & zero & 53 & 0.80 & 4.17 & 0.18 & 58 & 0.18 & 0.29 & 0.32 \\
\hline Jarczew & base & 58 & 1.25 & -0.44 & 0.69 & 56 & 1.24 & -0.29 & 0.44 \\
\hline PL0002R & noSurf & 58 & 1.25 & -0.43 & 0.69 & 56 & 1.24 & -0.29 & 0.44 \\
\hline Inland & zero & 58 & 1.21 & -0.41 & 0.68 & 56 & 1.24 & -0.29 & 0.44 \\
\hline Leba & base & 60 & 0.74 & -0.43 & 0.78 & 61 & 0.43 & 0.06 & 0.46 \\
\hline PL0004R & noSurf & 60 & 0.74 & -0.42 & 0.77 & 61 & 0.43 & 0.06 & 0.46 \\
\hline Coast & zero & 60 & 0.69 & -0.37 & 0.78 & 61 & 0.42 & 0.08 & 0.45 \\
\hline Råö & base & 60 & 0.33 & 0.22 & 0.68 & 61 & 0.26 & 0.31 & 0.38 \\
\hline SE0014R & noSurf & 60 & 0.33 & 0.23 & 0.68 & 61 & 0.26 & 0.32 & 0.38 \\
\hline Coast & zero & 60 & 0.34 & 0.45 & 0.67 & 61 & 0.28 & 0.37 & 0.36 \\
\hline
\end{tabular}




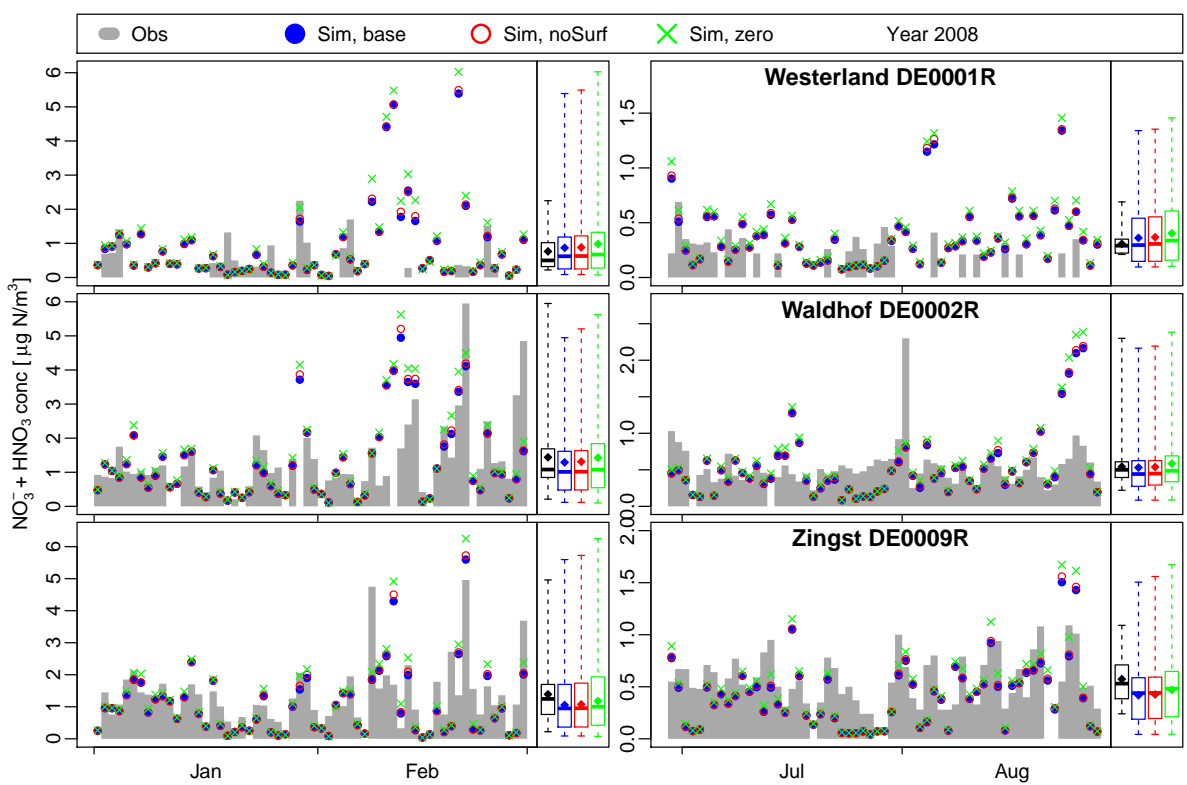

Figure 7. Similar to Fig. 6 but showing $\mathrm{sNO}_{3}$ values.

than during winter. The differences are also higher in regions with high nitrogen deposition.

Deactivating sea salt emissions completely (Fig. 9e and f; note the different scales compared to panels $\mathrm{c}$ and d) considerably reduces the nitrogen deposition in large parts of Denmark, the Netherlands, Belgium, and the southern UK by up to $10 \%$ and even more in a few regions. The nitrogen deposition into the southern North Sea is reduced as well. In turn, the nitrogen deposition increases considerably along the Norwegian Atlantic coast during winter and moderately in Eastern Europe during summer.

Table 6 shows the summed nitrogen deposition into the North and Baltic Sea in the four emission cases during winter and summer. The nitrogen deposition into the North Sea is approximately $7 \%$ higher during summer than during winter. In the Baltic Sea region, this difference is $6 \%$.

In the noSurf case, nitrogen deposition is reduced by less than $1 \%$ compared to the base case. In the zero case during winter, however, the nitrogen deposition into the North Sea is reduced by approximately $7 \%\left(\approx 22 \mathrm{kt} \mathrm{Nyr}^{-1}\right)$. During summer, it is reduced by only $2.6 \%$. The deposition difference for the Baltic Sea is considerably lower, with values of 3.4 and $0 \%$ for winter and summer, respectively. The deposition into the North Sea is not affected by applying salinity scaling (full case). However, nitrogen deposition into the Baltic Sea is slightly higher when no salinity scaling is applied.

Figure 10 and Table 7 show the nitrogen wet deposition in $\mathrm{kg} \mathrm{Nha}^{-1} \mathrm{~d}^{-1}$ at the known EMEP stations. Oxidized and reduced nitrogen is not individually considered here but given in the Supplement. The nitrogen deposition is underestimated in most measurement periods as the plots in Fig. 10 indicate. In a few situations, nitrogen deposition are overestimated at Waldhof and Zingst.

A comparison of the mean values in Table 7 confirms that the model considerably underestimates nitrogen wet deposition also at most other stations. Exceptions are the stations Zingst and Råö at which the nitrogen depositions are only slightly underestimated. The correlation coefficient is higher during winter than during summer. During summer, it is below 0.5 at four of seven stations. The Norwegian stations Birkenes and Hurdal and the Polish station Leba show the highest correlations throughout the year.

\section{Discussion}

\subsection{Salinity dependence and particle size spectra}

The salinity dependence of sea salt emissions was analyzed by Martensson et al. (2003) in laboratory studies. They found that for particles below $0.1 \mu \mathrm{m}$ dry radius, the number flux remains roughly unchanged, but the number flux distribution was shifted to smaller radii by a factor of $(S / 0.035)^{1 / 3}$ (Martensson et al., 2003, Fig. 5). Thus, the volume flux is reduced by $S / 0.035$ and the surface flux by $(S / 0.035)^{2 / 3}$. For particles larger than $0.1 \mu \mathrm{m}$ (dry radius), they found that the number flux was reduced by an order of magnitude. In the approach chosen in this study, the number, surface, and volume fluxes are all scaled by $S / 0.035$. Technically, this process was performed by scaling the fractions of the open ocean and surf zone in one input file by $S / 0.035$. The resulting salinity dependence is not in accordance with the findings of Martensson et al. (2003), in terms of either the fine particles or the coarse ones. However, this method was the only way 
Table 4. Similar to Table 2 but showing $\mathrm{sNO}_{3}\left(\mathrm{HNO}_{3}+\mathrm{NO}_{3}^{-}\right)$concentrations. Three sea salt emissions scenarios - base, noSurf, and zero - are considered.

\begin{tabular}{|c|c|c|c|c|c|c|c|c|c|}
\hline \multirow{2}{*}{$\begin{array}{l}\mathrm{sNO}_{3} \\
\text { Station }\end{array}$} & \multirow[b]{2}{*}{ Case } & \multicolumn{4}{|c|}{ Winter 2008} & \multicolumn{4}{|c|}{ Summer 2008} \\
\hline & & $n$ & RAE & MNB & $R$ & $n$ & RAE & MNB & $R$ \\
\hline Westerland & base & 21 & 0.76 & 1.17 & 0.10 & 26 & 0.25 & 0.41 & -0.14 \\
\hline DE0001R & noSurf & 21 & 0.76 & 1.19 & 0.10 & 26 & 0.26 & 0.43 & -0.14 \\
\hline Coast & zero & 21 & 0.81 & 1.48 & 0.11 & 26 & 0.28 & 0.57 & -0.13 \\
\hline Waldhof & base & 50 & 0.67 & 0.00 & 0.64 & 59 & 0.31 & 0.05 & 0.34 \\
\hline DE0002R & noSurf & 50 & 0.67 & 0.01 & 0.64 & 59 & 0.31 & 0.06 & 0.34 \\
\hline Inland & zero & 50 & 0.68 & 0.10 & 0.67 & 59 & 0.32 & 0.16 & 0.34 \\
\hline Neuglobsow & base & 53 & 0.59 & 0.39 & 0.63 & 54 & 0.25 & 0.04 & 0.39 \\
\hline DE0007R & noSurf & 53 & 0.59 & 0.40 & 0.63 & 54 & 0.25 & 0.05 & 0.39 \\
\hline Inland & zero & 53 & 0.62 & 0.50 & 0.65 & 54 & 0.26 & 0.16 & 0.41 \\
\hline Zingst & base & 54 & 0.56 & -0.17 & 0.76 & 56 & 0.26 & -0.23 & 0.55 \\
\hline DE0009R & noSurf & 54 & 0.57 & -0.16 & 0.76 & 56 & 0.26 & -0.22 & 0.55 \\
\hline Coast & zero & 54 & 0.58 & -0.08 & 0.77 & 56 & 0.26 & -0.14 & 0.55 \\
\hline Tange & base & 60 & 0.33 & 0.44 & 0.77 & 61 & 0.23 & -0.43 & 0.52 \\
\hline DK0003R & noSurf & 60 & 0.33 & 0.47 & 0.77 & 61 & 0.23 & -0.42 & 0.51 \\
\hline Inland & zero & 60 & 0.37 & 0.76 & 0.77 & 61 & 0.20 & -0.29 & 0.52 \\
\hline Keldsnor & base & 60 & 0.52 & -0.04 & 0.66 & 56 & 0.32 & -0.30 & 0.57 \\
\hline DK0005R & noSurf & 60 & 0.53 & -0.02 & 0.66 & 56 & 0.32 & -0.28 & 0.58 \\
\hline Coast & zero & 60 & 0.57 & 0.07 & 0.64 & 56 & 0.30 & -0.20 & 0.58 \\
\hline Anholt & base & 59 & 0.38 & -0.08 & 0.76 & 51 & 0.26 & -0.39 & 0.49 \\
\hline DK0008R & noSurf & 59 & 0.39 & -0.06 & 0.76 & 51 & 0.26 & -0.38 & 0.50 \\
\hline Coast & zero & 59 & 0.42 & 0.08 & 0.74 & 51 & 0.24 & -0.28 & 0.46 \\
\hline Ulborg & base & 60 & 0.34 & -0.25 & 0.74 & 55 & 0.23 & -0.48 & 0.59 \\
\hline DK0031R & noSurf & 60 & 0.35 & -0.23 & 0.74 & 55 & 0.22 & -0.47 & 0.60 \\
\hline Coast & zero & 60 & 0.38 & -0.09 & 0.75 & 55 & 0.21 & -0.38 & 0.59 \\
\hline Utö & base & 59 & 0.26 & 0.85 & 0.71 & 61 & 0.19 & -0.63 & 0.57 \\
\hline FI0009R & noSurf & 59 & 0.27 & 0.88 & 0.71 & 61 & 0.19 & -0.62 & 0.57 \\
\hline Coast & zero & 59 & 0.31 & 1.06 & 0.72 & 61 & 0.18 & -0.58 & 0.61 \\
\hline Virolahti II & base & 59 & 0.35 & 1.41 & 0.58 & 61 & 0.12 & -0.45 & 0.68 \\
\hline FI0017R & noSurf & 59 & 0.36 & 1.45 & 0.58 & 61 & 0.12 & -0.45 & 0.69 \\
\hline Coast & zero & 59 & 0.39 & 1.64 & 0.60 & 61 & 0.11 & -0.39 & 0.69 \\
\hline Birkenes & base & 60 & 0.19 & 1.24 & 0.45 & 52 & 0.17 & -0.30 & 0.18 \\
\hline NO0001R & noSurf & 60 & 0.19 & 1.25 & 0.45 & 52 & 0.17 & -0.28 & 0.20 \\
\hline Mixed & zero & 60 & 0.25 & 1.79 & 0.48 & 52 & 0.16 & -0.11 & 0.17 \\
\hline Hurdal & base & 60 & 0.34 & 1.86 & 0.44 & 52 & 0.11 & -0.36 & 0.34 \\
\hline NO0056R & noSurf & 60 & 0.35 & 1.90 & 0.45 & 52 & 0.11 & -0.35 & 0.35 \\
\hline Inland & zero & 60 & 0.39 & 2.15 & 0.43 & 52 & 0.11 & -0.22 & 0.34 \\
\hline Jarczew & base & 58 & 0.45 & -0.14 & 0.67 & 61 & 0.14 & -0.19 & 0.49 \\
\hline PL0002R & noSurf & 58 & 0.45 & -0.14 & 0.66 & 61 & 0.14 & -0.19 & 0.49 \\
\hline Inland & zero & 58 & 0.44 & -0.09 & 0.66 & 61 & 0.13 & -0.13 & 0.50 \\
\hline Leba & base & 60 & 0.34 & 0.13 & 0.75 & 61 & 0.14 & -0.03 & 0.51 \\
\hline PL0004R & noSurf & 60 & 0.35 & 0.14 & 0.76 & 61 & 0.14 & -0.01 & 0.50 \\
\hline Coast & zero & 60 & 0.37 & 0.24 & 0.75 & 61 & 0.16 & 0.10 & 0.52 \\
\hline Råö & base & 60 & 0.41 & 0.05 & 0.60 & 61 & 0.24 & -0.39 & 0.54 \\
\hline SE0014R & noSurf & 60 & 0.41 & 0.07 & 0.60 & 61 & 0.24 & -0.38 & 0.53 \\
\hline Coast & zero & 60 & 0.43 & 0.30 & 0.58 & 61 & 0.22 & -0.30 & 0.54 \\
\hline
\end{tabular}




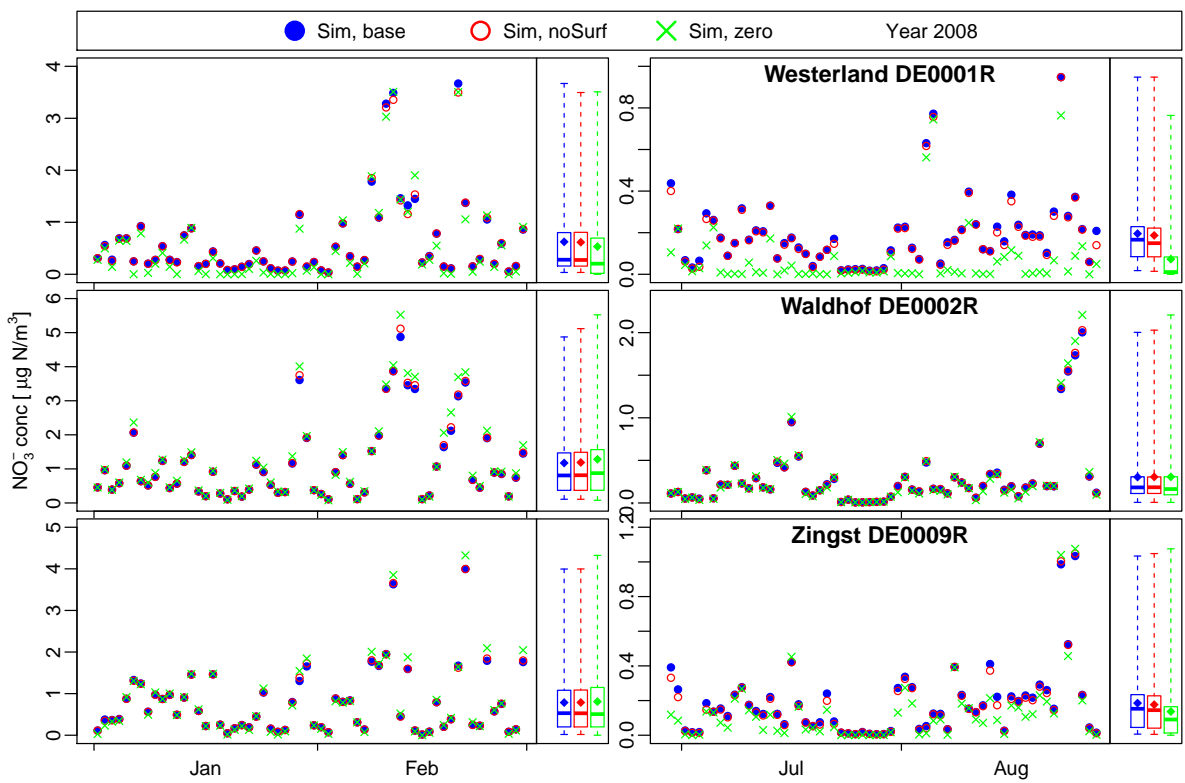

Figure 8. Similar to Fig. 6 but showing $\mathrm{NO}_{3}^{-}$values.

Table 5. MNB values of hourly $\mathrm{NO}_{3}^{-}$and $\mathrm{sNO}_{3}$ concentrations in the zero case with respect to the base case. Base case concentrations are considered as observations for the MNB calculation (see Eq. A2). Thus, positive values indicate the zero case concentrations exceed base case concentrations and negative concentrations indicate the opposite.

\begin{tabular}{lrrrrr}
\hline \multirow{2}{*}{ Station } & \multicolumn{2}{c}{ Winter } & & \multicolumn{2}{c}{ Summer } \\
\cline { 2 - 3 } \cline { 5 - 6 } & $\mathrm{NO}_{3}^{-}$ & $\mathrm{sNO}_{3}$ & & $\mathrm{NO}_{3}^{-}$ & $\mathrm{sNO}_{3}$ \\
\hline DE0001R & -0.55 & 0.09 & & -0.79 & 0.13 \\
DE0002R & 0.05 & 0.12 & & -0.19 & 0.11 \\
DE0007R & 0.00 & 0.11 & & -0.31 & 0.14 \\
DE0009R & -0.19 & 0.10 & & -0.54 & 0.12 \\
DE0044R & -0.02 & 0.10 & & -0.25 & 0.10 \\
DK0003R & 0.03 & 0.24 & & -0.35 & 0.25 \\
DK0005R & -0.17 & 0.12 & & -0.52 & 0.14 \\
DK0008R & -0.40 & 0.15 & & -0.75 & 0.16 \\
DK0031R & -0.35 & 0.20 & & -0.58 & 0.20 \\
FI0009R & -0.66 & 0.13 & & -0.85 & 0.15 \\
FI0017R & -0.49 & 0.11 & & -0.61 & 0.13 \\
NO0001R & -0.57 & 0.17 & & -0.76 & 0.30 \\
NO0056R & -0.28 & 0.07 & & -0.61 & 0.16 \\
PL0002R & -0.19 & 0.07 & & -0.36 & 0.10 \\
PL0004R & -0.34 & 0.09 & & -0.62 & 0.13 \\
SE0014R & -0.50 & 0.15 & & -0.80 & 0.16 \\
\hline
\end{tabular}

to include basic salinity dependence without modifying the CMAQ code. Thus, the chosen solution is easily applicable to other CMAQ versions and by other CMAQ users. Changing the CMAQ code would have meant that the changes needed to be applied in each new CMAQ version.
Two different sea salt fluxes exist: the sea salt surface flux and the effective sea salt flux. The effective sea salt flux represents the sea salt particles emitted from the sea surface that do not fall back into the ocean immediately. The surface flux represents all particles emitted from the sea surface. The effective flux is a combination of the surface flux and the atmospheric behavior of the sea salt particles which represents the surface emissions flux minus instant dry deposition. Martensson et al. (2003) measured the surface flux, whereas Gong (2003) described the effective flux. The shift in the number flux distribution of particles less than $1 \mu \mathrm{m}$ in size due to salinity variations, which Martensson et al. (2003) observed, might not be directly applicable to the effective flux. The shape of the distribution might change as well. Changes in the RH might alter the particle size distribution, as well. Additionally, de Leeuw et al. (2000, Sect. 6) noted that the bubble-bursting process itself might be affected by low-salinity conditions. Therefore, scaling bulk sea salt emissions by functions dependent upon salinity and RH is not necessarily a correct approach. Changes in the shape of the distribution need to be evaluated in the laboratory and in realworld studies.

\subsection{Discussion of the sea salt results}

The sodium concentrations were well matched in terms of the order of magnitude and the temporal occurrence of peaks. Measurements at Zingst, Utö, and Virolahti II showed that sea salt emissions were considerably overestimated in this region when salinity scaling was not applied. Therefore, salinity downscaling is important. Further studies should in- 


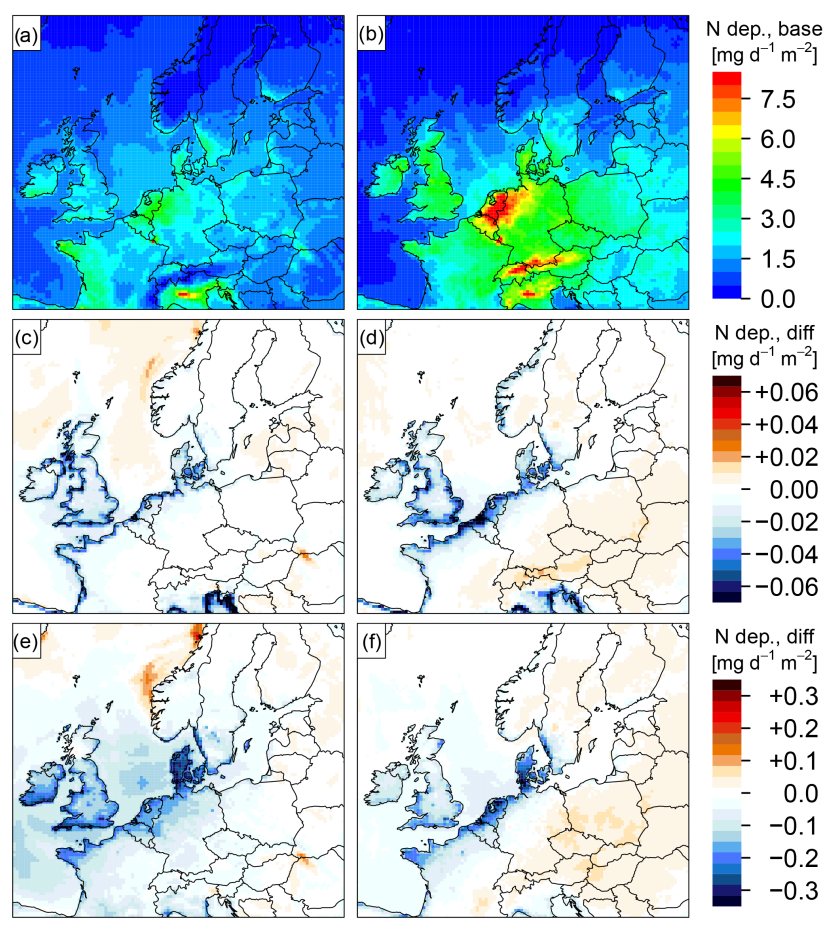

Figure 9. Total nitrogen deposition (dry plus wet deposition) in $\mathrm{mg} \mathrm{N} \mathrm{m}^{-2} \mathrm{~d}^{-1}$ in the study region during winter (a, c, e) and during summer (b, d, f). (a, b) Nitrogen deposition in the base case; (c, d) nitrogen deposition difference between noSurf and base case (noSurf - base); (e, f) nitrogen deposition difference between zero and base case (zero - base). Note: The color scale of the plots (c) and (d) is different from that of the plots (e) and (f).

vestigate whether an improved downscaling procedure (see Sect. 4.1) improves predicted sea salt concentrations.

Sodium concentrations are overpredicted at all stations during summer. During winter, however, sea salt concentrations tend to be overpredicted at coastal stations and underpredicted at inland stations. The inland station Tange shows overpredictions throughout the year. Amongst the inland stations, Tange is located closest to the coast. The pattern of overpredictions at the coast and underpredictions inland may be due to a combination of overpredicted sea salt emissions and overpredicted dry deposition velocities for coarse sea salt particles. Additionally, certain peaks are better matched in terms of magnitude than others. This difference may be attributable to meteorological conditions, droplet generation processes missing from Gong's sea salt emission parameterization, the SST, and the sea surface micro layer (SML).

Based on laboratory studies, Martensson et al. (2003) found that the sea salt emission size spectrum depends on SST. Jaeglé et al. (2011) and Gantt et al. (2015) improved sea salt particle model results by applying SST dependence to sea salt source functions. The results of Martensson et al. (2003), Jaeglé et al. (2011), Callaghan et al. (2014), and Salter et al. (2015) clearly show that sea salt emissions de- crease when the SST decreases. The $\mathrm{Na}^{+}$concentrations might be overestimated at coastal stations during winter because Gong (2003) does not consider the SST when calculating sea salt emissions. However, this factor does not explain the general overestimation in summer.

The SML that is formed by mainly surface active organic compounds affects the bubble-bursting process and, thus, sea salt emissions. Because the marine biological activity is higher during summer than during winter, one might expect that the SML affects sea salt emissions more during summer than during winter. This could explain the general overestimation of $\mathrm{Na}^{+}$concentrations during summer. However, the impact of the SML on sea salt emissions is currently poorly understood and little investigated.

Because Gong's parameterization lacks SST and SML dependence, splash, and spume droplet generation, and nonwind-related bubble bursting, repeating the simulations with other sea salt emission parameterizations might yield interesting results. To analyze the impact of the SML, satellitederived chlorophyll $a$ data could be correlated with the deviations between the measured and modeled results. However, chlorophyll $a$ data may not be the ideal proxy (Fuentes et al., 2010).

Under low wind conditions, surf zone emissions are a major source of atmospheric sea salt in the coastal grid cells. The contribution of these emissions decreases under high wind conditions (Fig. 4). In this study, the maximum fraction of surf zone per grid cell $(24 \mathrm{~km} \times 24 \mathrm{~km}$ grid $)$ was capped at $0.47 \%$ to reduce the amount of surf zone emissions. Commonly, this parameter is not capped. Without capping, the fraction of surf zone was considerably greater in certain coastal grid cells, particularly along the Norwegian Atlantic coast, with its numerous fjords and islands. Not capping the surf zone would have led to considerably higher surf zone emissions. Along the Dutch, German, and western Danish coast, most grid cells were not affected by the capping (see Supplement, Fig. S2). De Leeuw et al. (2000) found through measurements at a beach in late January that surf zone emissions can contribute approximately 10 times more to ambient atmospheric sea salt concentrations than open ocean emissions. However, at other times, surf zones contribute just 0.1 times as much as the open ocean. The surf zone emissions in grid cells with a large proportion of surf zone, without capping, might be comparable to the maximum-contribution situations observed in de Leeuw et al. (2000). However, the observed high contributions did not occur continuously. Additionally, the measurements were collected in January, when winds are stronger than those in summer. Therefore, the modeled surf zone emissions were reduced by capping the surf zone fraction. Mechanistically, modifying the white cap coverage would have been more correct. In the new CMAQ v5.1 release, surf zone emissions will be reduced by $50 \%$ by setting the white cap coverage to 0.5 . This step was not included in this study because changes in the CMAQ code were avoided in order to make the chosen procedure simpler and 
Table 6. Nitrogen deposition into the North Sea and Baltic Sea in $\mathrm{ktN}^{-1}$ in the base, noSurf, zero, and full cases during winter and summer. The North Sea and Baltic Sea cover $6.50 \times 10^{11}$ and $4.13 \times 10^{11} \mathrm{~m}^{2}$, respectively, in this study's model setup. The exact regions considered are plotted in Sect. S6 of the Supplement.

\begin{tabular}{|c|c|c|c|c|c|c|}
\hline Region & Season & Base & NoSurf & Zero & Full & \\
\hline \multirow{2}{*}{ North Sea } & winter & 1.01 & 1.00 & 0.94 & 1.01 & \multirow{2}{*}{$\mathrm{ktNd}^{-1}$} \\
\hline & summer & 1.08 & 1.08 & 1.05 & 1.08 & \\
\hline \multirow{2}{*}{ Baltic Sea } & winter & 0.57 & 0.56 & 0.55 & 0.58 & \multirow{2}{*}{$\mathrm{ktNd}^{-1}$} \\
\hline & summer & 0.60 & 0.60 & 0.60 & 0.61 & \\
\hline \multirow{2}{*}{ North Sea } & winter & $100.0 \%$ & $99.7 \%$ & $93.1 \%$ & $99.9 \%$ & \multirow{2}{*}{ rel. to base } \\
\hline & summer & $100.0 \%$ & $99.7 \%$ & $97.4 \%$ & $100.0 \%$ & \\
\hline \multirow{2}{*}{ Baltic Sea } & winter & $100.0 \%$ & $99.8 \%$ & $96.6 \%$ & $103.2 \%$ & \multirow{2}{*}{ rel. to base } \\
\hline & summer & $100.0 \%$ & $99.9 \%$ & $100.0 \%$ & $101.2 \%$ & \\
\hline
\end{tabular}

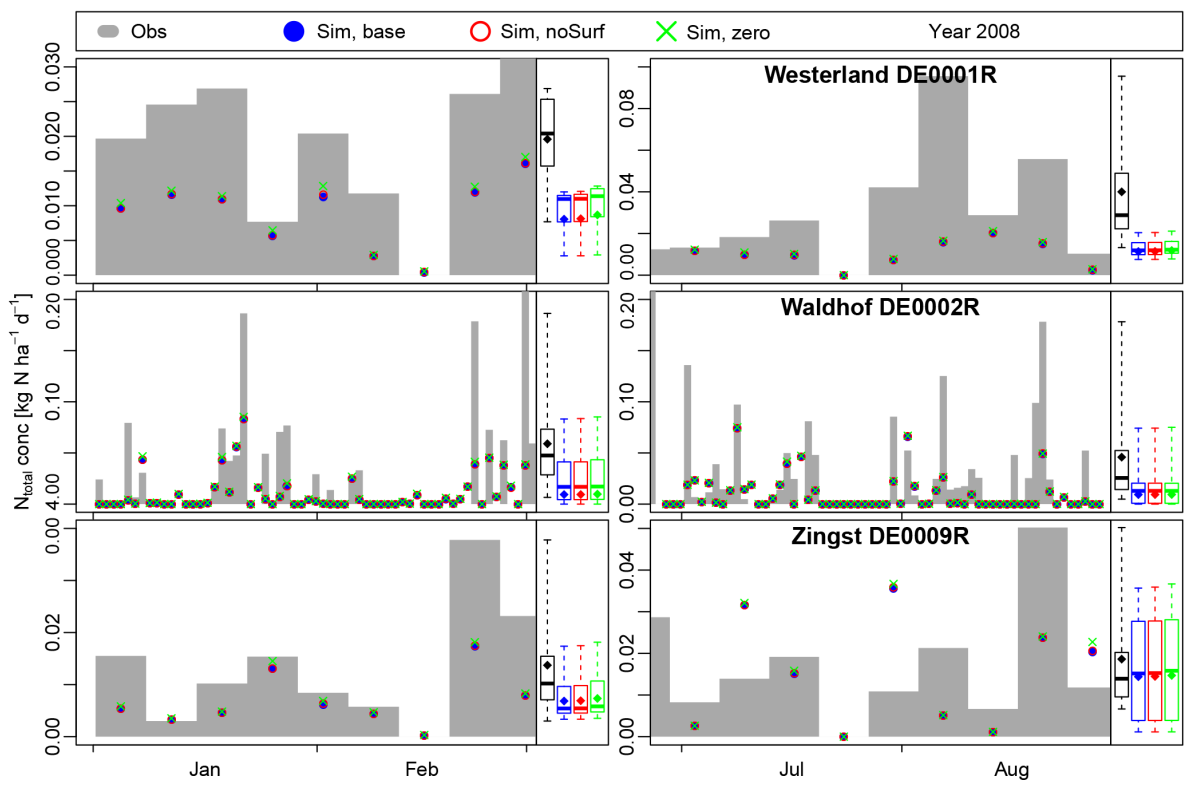

Figure 10. Similar to Fig. 6 but showing nitrogen (reduced and oxidized) deposition $\left(\mathrm{kg} \mathrm{Nha}^{-1} \mathrm{~d}^{-1}\right)$. The different interval length is due to different measurement intervals at the individual stations.

more applicable in other CMAQ versions. As an alternative, one might choose another parameterization for the surf zone emissions. For example, de Leeuw et al. (2000) and Chomka and Petelski (1997) presented alternative surf zone emission parameterizations. In their study, which was discussed above, de Leeuw et al. (2000) analyzed measured surf-zone-related sea salt concentrations, meteorological data, and video data of the surf zone. They found no correlation between surf zone width or wave height and the surf zone production of sea salt.

Im (2013) estimated a considerably higher contribution of surf zone emissions to atmospheric sea salt concentrations. In that study, the surf zone fraction per grid cell was not capped and was calculated by multiplying the length of the coastlines by $50 \mathrm{~m}$ (and dividing by grid cell area). In our study, the surf zone size was calculated in a way so as to not count overlapping surf zones twice. Additionally, the Greek coastal waters contain more islands and the coastline is less straight than the man-made coastlines of the Netherlands and Germany. Therefore, the surf zone contribution estimated in this study is lower.

Salinity in coastal waters is commonly lower than in open ocean water due to freshwater inflow. Thus, surf zone emissions are indirectly scaled down in this study. $\operatorname{Im}(2013)$ and Kelly et al. $(2010,2014)$ do not consider salinity. Hence, this study's surf zone emissions are reduced compared to those in the named studies due to salinity-dependent scaling.

Sea ice is not considered in this study. If the sea surface is covered with sea ice, no sea salt particles are emitted by bursting bubbles. Therefore, sea salt emissions can be deactivated in regions with sea ice cover. For the study region, sea surface salinity is very low in areas with significant sea ice cover (northeastern Baltic Sea). Additionally, these areas 
Table 7. Similar to Table 2 but showing $R$ and mean values of model $\left(\mu_{\text {sim }}\right)$ and observational data $\left(\mu_{\text {obs }}\right)$ of nitrogen wet deposition $\left(\mathrm{kg} \mathrm{Nha}^{-1} \mathrm{~d}^{-1}\right)$ for the base case. Reduced nitrogen and oxidized nitrogen are not shown individually. $R$ of time series with a length of 10 or shorter is not shown. The length of the measurement intervals at the individual stations varies between 1 day, 1 week, and 2 weeks. Therefore, the number of measurements intervals for the comparison differs considerably between the stations.

\begin{tabular}{|c|c|c|c|c|c|c|c|c|}
\hline \multirow[t]{2}{*}{ STATION } & \multicolumn{4}{|c|}{ Winter } & \multicolumn{4}{|c|}{ Summer } \\
\hline & $n$ & $R$ & $\mu_{\mathrm{sim}}$ & $\mu_{\mathrm{obs}}$ & $n$ & $R$ & $\mu_{\text {sim }}$ & $\mu_{\mathrm{obs}}$ \\
\hline DE0001R & 7 & - & 0.009 & 0.020 & 7 & - & 0.013 & 0.040 \\
\hline DE0002R & 19 & 0.56 & 0.023 & 0.059 & 30 & 0.20 & 0.016 & 0.046 \\
\hline DE0007R & 22 & 0.42 & 0.017 & 0.034 & 22 & 0.10 & 0.013 & 0.050 \\
\hline DE0009R & 7 & - & 0.008 & 0.014 & 7 & - & 0.016 & 0.019 \\
\hline DE0044R & 6 & - & 0.008 & 0.016 & 8 & - & 0.014 & 0.032 \\
\hline DK0005R & 3 & - & 0.006 & 0.010 & 4 & - & 0.013 & 0.024 \\
\hline DK0008R & 3 & - & 0.011 & 0.013 & 4 & - & 0.018 & 0.015 \\
\hline DK0031R & 3 & - & 0.007 & 0.023 & 4 & - & 0.013 & 0.018 \\
\hline FI0017R & 7 & - & 0.006 & 0.019 & 8 & - & 0.008 & 0.012 \\
\hline NO0001R & 36 & 0.68 & 0.012 & 0.079 & 27 & 0.66 & 0.019 & 0.032 \\
\hline NO0056R & 25 & 0.60 & 0.000 & 0.054 & 28 & 0.54 & 0.008 & 0.028 \\
\hline PL0002R & 24 & 0.71 & 0.010 & 0.045 & 17 & -0.34 & 0.008 & 0.079 \\
\hline PL0004R & 31 & 0.55 & 0.013 & 0.030 & 28 & 0.59 & 0.020 & 0.035 \\
\hline SE0014R & 38 & 0.62 & 0.013 & 0.038 & 26 & 0.20 & 0.032 & 0.033 \\
\hline
\end{tabular}

are commonly downwind relative to the considered EMEP stations, except the two Finish stations Utö and Virolahti II. Therefore, the overestimation of sea salt emissions introduced by not considering sea ice is expected to be negligible. Moreover, sea salt particles have been found to be re-emitted by wind-blown snow from sea ice (Tian-Kunze et al., 2009; Yang et al., 2008). Additionally, the edges of sea ice required a similar treatment as the surf zone. Therefore, deactivating sea salt emissions above sea ice would not necessarily improve sea salt emission prediction quality.

\subsection{Discussion of atmospheric nitrogen compounds}

The concentrations of $\mathrm{sNH}_{4}$ were found to be well matched at Zingst, underpredicted at Westerland, and overpredicted at Waldhof. Because land-based $\mathrm{NH}_{3}$ emissions are not the topic of this paper, Waldhof will not be discussed further. Backes et al. (2016a) described and discussed the employed $\mathrm{NH}_{3}$ emissions in detail.

A 1-week episode of northeasterly winds during the end of July corresponds in the time series plots to a strong decline in $\mathrm{sNH}_{4}$ concentrations at Zingst and a strong increase at Westerland. The increase at Westerland is due to $\mathrm{NH}_{3}-$ rich air from Denmark. Although modeled concentrations increased considerably, measured concentrations increased even more. This result might be due to underpredicted emissions or overpredicted $\mathrm{NH}_{3} / \mathrm{NH}_{4}^{+}$deposition. The discrepancy is not caused by sea salt. Remarkably, at Zingst, the modeled $\mathrm{sNH}_{4}$ concentrations decreased, whereas the measured concentrations increased during this episode. No major landmasses are on the route between the Swedish coast and Zingst, the path by which the air masses likely traveled. If we consider the measured $\mathrm{NH}_{3}$ and $\mathrm{NH}_{4}^{+}$concentrations individually (which one should not do; EMEP, 2014, Chp. 3), the measured $\mathrm{sNH}_{4}$ consists primarily of $\mathrm{NH}_{3}$ ( $>95 \%$ by mass, not shown here). Because $\mathrm{NH}_{3}$ has a short atmospheric lifespan, we assume that most $\mathrm{sNH}_{4}$ is transported over a short distance and does not originate from Sweden. The $\mathrm{NH}_{3}$ may be emitted from the sea surface (Barrett, 1998; Paulot et al., 2015). Norman and Leck (2005) found oceanic emissions to be relevant contributors to atmospheric $\mathrm{NH}_{3}$ in remote marine regions. These oceanic $\mathrm{NH}_{3}$ emissions would explain the generally underpredicted concentrations at coastal stations. However, these emissions are approximately 2 to 3 orders of magnitude lower than land-based emissions. Additionally, a brief examination of chlorophyll $a$ data (Lavender et al., 2015) does not indicate the presence of algae blooms. Therefore, marine $\mathrm{NH}_{3}$ cannot account for the entire difference at Zingst. Another reason might be incorrectly predicted wind directions caused by sea and land breezes and planetary boundary layer height (e.g., Miao et al., 2009). Sea and land breezes during day and night do not form in COSMO-CLM with the given setup, version, and grid resolution (M. Schulz, personal communication, 2015). Furthermore, certain landbased $\mathrm{NH}_{3}$ sources, which are located close to the measurement station, might not be considered by the employed emission data set. This topic needs to be considered further.

Predicted and measured $\mathrm{sNO}_{3}$ concentrations are not well correlated at Westerland in either seasons and at all stations in summer. Approximately half of the measurements at Westerland were under the detection limit and not in the EMEP database. Thus, the peak concentrations were measured and compared. Comparing peak concentrations is biased because they are often over- or underestimated, e.g., via smoothing in 
the discretization. Therefore, an analysis of the $\mathrm{sNO}_{3}$ Westerland data is problematic. Additionally, peaks arise in the model results that do not exist in the measurements. This effect may be due to the employed shipping emission inventory, which contains the weekly averaged shipping emissions of 2011 (whereas the model year is 2008) or due to problems with the measurements.

Surf zone emissions of sea salt have a negligible impact on atmospheric $\mathrm{sNH}_{4}$ and $\mathrm{sNO}_{3}$ concentrations at most EMEP stations. Deactivating sea salt emissions completely showed that sea salt particles slightly affect the $\mathrm{sNH}_{4}$ and $\mathrm{sNO}_{3}$ concentrations: these concentrations rose when sea salt was deactivated, which means that the presence of sea salt particles decreases them. $\mathrm{NO}_{3}^{-}$concentrations, in contrast, increase in the presence of sea salt at most stations throughout the year. At some inland stations, sea salt particles lead to a decrease in $\mathrm{NO}_{3}^{-}$concentrations. Additionally, the negative MNB values of other inland stations are closer to 0 than those of coastal stations. Thus, the impact of sea salt particles on $\mathrm{NO}_{3}^{-}$decreases with distance from the coast. This pattern is expected because sea salt concentrations decrease from the coast to inland locations. As Fig. 8 indicates, the zero case $\mathrm{NO}_{3}^{-}$peak concentrations are higher than base case peak concentrations although the MNBs are negative. Therefore, the impact of sea salt on $\mathrm{NO}_{3}^{-}$is not as clear as one might assume from the table of MNB values.

Im (2013), Liu et al. (2015) and Kelly et al. (2014) found that sea salt has a significant impact on atmospheric nitrate concentrations. In Im (2013) and Liu et al. (2015), particulate nitrate concentrations considerably increased when sea salt was added. They increased even more when surf zone emissions were activated (Im, 2013, Table 4). For summer months, their results agree completely with the results of this study but inland stations deviate during winter. Additionally, the peak concentrations differ from the MNBs in this study and the result of other studies. The emission and meteorological regimes in the Mediterranean and Pearl River Delta regions are different from those in the North Sea region, which may account for the different behavior. Due to high agricultural activity in the North Sea region, sufficient fine particles and ammonia are available in summer months for the condensation of ammonium nitrate onto existing particles. As described above, ammonium and nitrate concentrations correlate well in the model but are less correlated in reality. If the nitrate condensation is $\mathrm{NH}_{3}$ limited in the Mediterranean region, modeled nitrate may condense on particles only in exchange for the release of $\mathrm{HCl}$. According to the other studies, $\mathrm{HCl}$ displacement is a relevant process in those regions. Hence, comparing the $\mathrm{NH}_{3} / \mathrm{NH}_{4}^{+}$concentrations would be interesting. Additionally, Saharan dust is blown from the boundaries into the model domain of Im (2013). The dust may have an indirect effect on atmospheric chemistry that is not present in this study because desert dust is not included in the boundary conditions of this study.

\subsection{Discussion of nitrogen deposition}

The nitrogen deposition is higher during summer because the nitrogen emissions are higher during summer, too. While anthropogenic $\mathrm{NO}_{x}$ emissions are higher in winter due to residential heating, $\mathrm{NH}_{3}$ emissions are considerably higher during summer due to animal husbandry and agricultural activities (involving, for example, fertilizers and manure). The Po Valley is an exception. It is one of the largest and densest industrialized regions in Europe and features high $\mathrm{NO}_{x}$ emissions throughout the year leading to the high nitrogen depositions.

A comparison of modeled and measured nitrogen wet depositions showed that the wet deposition is underestimated by the model by up to a factor of two.

The nitrogen deposition into the North Sea was $1.01 \mathrm{kt} \mathrm{N} \mathrm{d}^{-1}\left(369 \mathrm{kt} \mathrm{Nyr}^{-1}\right)$ during winter and $1.08 \mathrm{kt} \mathrm{N} \mathrm{d}^{-1}$ $\left(395 \mathrm{kt} \mathrm{Nyr}^{-1}\right)$ during summer in the year 2008. The literature values are $622 \mathrm{ktNyr}^{-1}$ (de Leeuw et al., 2003), $709 \mathrm{kt} \mathrm{Nyr}^{-1}$ (Hertel et al., 2002), and $430 \mathrm{kt} \mathrm{Nyr}^{-1}$ (Bartnicki and Fagerli, 2008) for the whole years 2003, 1999, and 2005, respectively. These literature annual values are considerably higher than the winter and summer results in this study. The North Sea is defined similar to the OSPAR region II in the cited publications and in this study. Thus, the English Channel (until approximately $5^{\circ} \mathrm{W}$ ) and the Skagerrak are considered to be parts of the North Sea. Therefore, the considered North Sea area is comparable between the studies. In this study, the Baltic Sea featured nitrogen deposition of $0.57 \mathrm{kt} \mathrm{N} \mathrm{d}^{-1}\left(207 \mathrm{kt} \mathrm{Nyr}^{-1}\right)$ during winter and $0.60 \mathrm{kt} \mathrm{N} \mathrm{d}^{-1}\left(220 \mathrm{kt} \mathrm{Nyr}^{-1}\right)$ during summer, whereas $264 \mathrm{kt} \mathrm{Nyr}^{-1}$ (HELCOM, 2005), $204 \mathrm{kt} \mathrm{Nyr}^{-1}$ (Bartnicki and Fagerli, 2008), 201-300 $\mathrm{kt} \mathrm{N} \mathrm{yr}^{-1}$ (Langner et al., 2009), and $\approx 200 \mathrm{ktNyr}^{-1}$ (Bartnicki et al., 2011) were found in other studies for the years 2000, 2005, 1992-2001, and 2006, respectively. Although Bartnicki and Fagerli (2008) and Bartnicki et al. (2011) obtained results similar to those in this study, HELCOM (2005) and Langner et al. (2009) estimated deposition rates that were considerably higher and similar to those of the North Sea.

One reason for lower nitrogen deposition in this study compared to other ones might be that the nitrogen deposition in other months was considerably higher. Additionally, interannual variation in the meteorological conditions and nitrogen emissions might have contributed to the low results in this study. The nitrogen deposition might be generally underestimated in the model setup because of the underestimation in the wet deposition. However, it is not known whether the dry deposition compensates the latter underestimation. The nitrogen deposition along the coastline is considerably higher than at the open ocean (see Fig. 9) which is caused by the coincidence of marine coarse sea salt particles and nitrogen species emitted on the land. Thus, the procedure of dividing the nitrogen deposition between deposition into wa- 
ter and deposition onto land in coastal regions might lead to differences in the stated nitrogen deposition.

The surf zone sea salt emissions do affect nitrogen deposition in coastal regions, but the effect is very small (Fig. 9). The impact of the surf zone emissions on the nitrogen deposition into the entire North Sea and Baltic Sea is negligible (Table 6).

In general, sea salt particles considerably increase the nitrogen deposition in coastal regions and, particularly, in Denmark. Additionally, the nitrogen deposition above the open ocean is affected. The Po Valley nitrogen deposition is nearly unaffected by sea salt emissions because the sea salt concentrations are very low in this region due to its geographic location.

The impact of sea salt emissions on the nitrogen deposition into the Baltic Sea is generally small. Because the full and base case lead to quite similar nitrogen depositions, we assume that the low impact is not caused by the salinity-scaled sea salt emissions and is instead due to low nitrogen emissions upwind of the Baltic Sea. However, a comparison of the zero, base, and full cases indicates that sea-salt-induced nitrogen deposition would be twice as high if no salinity scaling was applied.

The salinity scaling (base vs. full) is not relevant for nitrogen deposition into the North Sea. However, sea-salt-induced nitrogen deposition is higher than in the Baltic Sea region. During winter, $\approx 7 \%$ is induced by sea salt. Unfortunately, we are not aware of comparable studies on the impact of sea salt particles on nitrogen deposition into the North Sea.

\section{Conclusions}

Measured sea salt concentrations are fairly well represented in the given model setup. Commonly, sea salt peak concentrations are overestimated. The current parameterization might overestimate sea salt emissions under strong wind conditions during the winter. This overestimation should be evaluated in future studies. A few peak concentrations are underestimated, indicating that one or more sea salt particle generation processes are not considered in the current sea salt emission parameterizations. These parameterizations should be tested with alternative sea salt emission source functions to determine whether these alternatives provide better predictions in these situations. However, the underestimated peak concentrations may be due to differences between the modeled meteorology and the real-world meteorology, as well. The evaluation of the Zingst, Utö, and Virolahti II data in Fig. 5 and Table 2 clearly shows that salinity-dependent scaling of sea salt emissions is important in marginal seas with salinities that differ from $35 \%$.
Surf zone emissions do not generally improve or deteriorate estimated sea salt concentrations in the presented model setup. Their effect on $\mathrm{sNH}_{4}, \mathrm{sNO}_{3}$, and $\mathrm{NO}_{3}^{-}$on its own is negligible. At a finer grid resolution, however, the impact of surf zone emissions might be relevant due to a relatively higher surf zone fraction. The concentrations of $\mathrm{sNH}_{4}$ and $\mathrm{sNO}_{3}$ increased when sea salt emissions were deactivated, although the effect is small. In contrast, the MNBs for the $\mathrm{NO}_{3}^{-}$time series decreased except at inland stations during winter where the $\mathrm{MNB}$ increased. However, $\mathrm{NO}_{3}^{-}$peak concentrations in the absence of sea salt emissions often exceeded the peak concentrations in the presence of sea salt emissions, which contradicts the MNB values. Im (2013), Liu et al. (2015) and Kelly et al. (2014) found that sea salt had a strong negative impact on nitrate, which agrees with the summer MNB results but disagrees with the winter results at inland stations and with peak concentrations. We assume that this difference is due to different emission and air pollution regimes, especially with respect to $\mathrm{NH}_{3}$ emissions. In one 10-day episode in late July, $\mathrm{sNH}_{4}$ concentrations were considerably underestimated by the model. The reason for this is unclear. However, this underestimation is not related to sea salt particles.

Surf zone sea salt emissions have a negligible effect on the nitrogen deposition. However, sea salt emissions in general have a relevant impact on nitrogen deposition in some regions, and this impact varies intra-annually. Therefore, sea salt emissions need to be considered in nitrogen deposition studies. The literature values on the modeled total nitrogen deposition into the North Sea are up to a factor of 2 as high as the nitrogen deposition in this study. The nitrogen wet deposition is underestimated in this study's model setup which might lead to an underestimation of the total nitrogen deposition. However, it is unknown how accurate the model predicts the nitrogen dry deposition and whether the model tends to over- or underestimate the dry deposition.

For an improved validation, it would be favorable to have individual measurements of $\mathrm{NO}_{3}^{-}, \mathrm{HNO}_{3}, \mathrm{NH}_{4}^{+}$, and $\mathrm{NH}_{3}$ available. Data from both coastal and inland stations are needed to evaluate whether either the emission parameterization or modeled atmospheric transport processes lead to observed discrepancies. Size-resolved sea salt measurements would be of high value for this process. Finally, more experimental work is needed to determine parameterizations for surf zone emissions. 


\section{Appendix A: Statistical evaluation}

The statistical measures RAE, MNB, and $R$ are calculated according to Eqs. (A1), (A2), and (A3), respectively.

$\mathrm{RAE}=\frac{1}{n} \times \sum_{i=1}^{n}\left|P_{i}-O_{i}\right|$

$\mathrm{MNB}=\frac{1}{n} \times \sum_{i=1}^{n} \frac{P_{i}-O_{i}}{O_{i}}$

$R=1-\frac{6}{n\left(n^{2}-1\right)} \times \sum_{i=1}^{n}\left(P_{i}-O_{i}\right)^{2}$

$P_{i}$ is $i$ th predicted value, $p_{i}$ is the rank of the $i$ th predicted value, $O_{i}$ is the $i$ th observed value, $o_{i}$ is the rank of the $i$ th observed value, and $n$ is the number of observations.

\section{Appendix B: Deposition calculation}

The nitrogen deposition is calculated from the dry and wet depositions of $\mathrm{NO}, \mathrm{NO}_{2}, \mathrm{HNO}_{3}, \mathrm{NO}_{3}^{-}, \mathrm{NH}_{3}, \mathrm{NH}_{4}^{+}, \mathrm{NO}_{3}$,
HONO, peroxyacyl nitrate (PAN), and peroxynitric acid (PNA) according to Eqs. (B1) to (B3). $\mathrm{HNO}_{3}$ and $\mathrm{NO}_{3}^{-}$as well as $\mathrm{NH}_{3}$ and $\mathrm{NH}_{4}^{+}$are separately listed in the CMAQ wet deposition output in order to distinguish the amount of particulate (ions) and gas compounds that were washed out.

$$
\begin{aligned}
& \text { WetDep }_{\mathrm{N}}=M_{\mathrm{N}} \times \sum_{s \in \text { species }} \frac{\text { WetDep }_{s}}{M_{s}} \\
& \text { DryDep }_{\mathrm{N}}=M_{\mathrm{N}} \times \sum_{s \in \text { species }} \frac{\text { DryDep }_{s}}{M_{s}} \\
& \operatorname{Dep}_{N}=\operatorname{DryDep}_{N}+\text { WetDep }_{N} \\
& \text { species }=\left\{\mathrm{NO}, \mathrm{NO}_{2}, \mathrm{HNO}_{3}, \mathrm{NO}_{3}^{-}, \mathrm{NH}_{3}, \mathrm{NH}_{4}^{+}, \mathrm{NO}_{3}\right. \text {, } \\
& \text { HONO, PAN, PNA\} }
\end{aligned}
$$

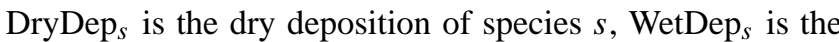
wet deposition of species $s$, Dep ${ }_{s}$ is the deposition of species $s$ (sum of dry and wet deposition), and $M_{s}$ is the molar mass of species $s$. 


\section{The Supplement related to this article is available online at doi:10.5194/acp-16-2921-2016-supplement.}

Acknowledgements. Beate Geyer provided COSMO-CLM meteorology data which can be accessed via the Climate and Environmental Retrieval and Archive (CERA) of the German Climate Computing Centre (DKRZ). Salinity data were extracted from ECOSMO simulations by Corinna Schrum. We thank Anna Backes, Matthias Karl, and Markus Schultze from our institute of discussions on the model results. Additionally, Anna Backes provided GIS-related data for this study. Uma Shankar, James Kelly, and Brett Gantt (US EPA) provided very detailed answer to questions about the inline sea salt emissions of CMAQ. A general thanks goes out to the US EPA and the CMAQ development team for providing this high-quality chemistry transport model as an open-source product. The EMEP measurement data were extracted from the EBAS database which is maintained and further developed by the Norwegian Institute for Air Research (NILU). Statistical evaluation and most plotting were performed using $\mathrm{R}$. The remaining plots were created with the Generic Mapping Tools (GMT) developed and maintained by Paul Wessel, Walter H. F. Smith, Remko Scharroo, Joaquim Luis, and Florian Wobbe. The simulation data were processed with the Climate Data Operators (cdo) by Uwe SchultzWeider from the Max Planck Institute for Meteorology and with the netCDF Operators (NCO) by Charlie Zender and Henry Butowsky. Parts of the study were funded by the project "Measurements of shipping emissions in the marine troposphere" (MeSMarT) of the German Federal Maritime and Hydrographic Agency (Bundesamt für Seeschifffahrt und Hydrographie).

The article processing charges for this open-access

publication were covered by a Research

Centre of the Helmholtz Association.

Edited by: M. C. Facchini

\section{References}

Aulinger, A., Matthias, V., Zeretzke, M., Bieser, J., Quante, M., and Backes, A.: The impact of shipping emissions on air pollution in the greater North Sea region - Part 1: Current emissions and concentrations, Atmos. Chem. Phys., 16, 739-758, doi:10.5194/acp16-739-2016, 2016.

Backes, A., Aulinger, A., Bieser, J., Matthias, V., and Quante, M.: Ammonia Emissions In Europe, Part I: Development of a dynamical ammonia emissions inventory, Atmos. Environ., 131, 55-66, doi:10.1016/j.atmosenv.2016.01.041, 2016a.

Backes, A., Aulinger, A., Bieser, J., Matthias, V., and Quante, M.: Ammonia emissions in Europe, Part II: How ammonia emission abatement strategies affect secondary aerosols, Atmos. Environ., 126, 153-161, doi:10.1016/j.atmosenv.2015.11.039, 2016b.

Barrett, K.: Oceanic ammonia emissions in Europe and their transboundary fluxes, Atmos. Environ., 32, 381-391, doi:10.1016/S1352-2310(97)00279-3, 1998.
Barthel, K., Daewel, U., Pushpadas, D., Schrum, C., Årthun, M., and Wehde, H.: Resolving frontal structures: on the payoff using a less diffusive but computationally more expensive advection scheme, Ocean Dynam., 62, 1457-1470, doi:10.1007/s10236012-0578-9, 2012.

Bartnicki, J. and Fagerli, H.: Airborne load of nitrogen to European seas, Ecol. Chem. Eng. S, 15, 297-313, 2008.

Bartnicki, J., Semeena, V. S., and Fagerli, H.: Atmospheric deposition of nitrogen to the Baltic Sea in the period 1995-2006, Atmos. Chem. Phys., 11, 10057-10069, doi:10.5194/acp-1110057-2011, 2011.

Bieser, J., Aulinger, A., Matthias, V., Quante, M., and Builtjes, P.: SMOKE for Europe - adaptation, modification and evaluation of a comprehensive emission model for Europe, Geosci. Model Dev., 4, 47-68, doi:10.5194/gmd-4-47-2011, 2011.

Binkowski, F. S. and Roselle, S. J.: Models-3 Community Multiscale Air Quality (CMAQ) model aerosol component 1. Model description, J. Geophys. Res.-Atmos., 108, 4183, doi:10.1029/2001JD001409, 2003.

Bowyer, P. A., Woolf, D. K., and Monahan, E. C.: Temperature dependence of the charge and aerosol production associated with a breaking wave in a whitecap simulation tank, J. Geophys. Res.Oceans, 95, 5313-5319, doi:10.1029/JC095iC04p05313, 1990.

Cai, X., Ziemba, L. D., and Griffin, R. J.: Secondary aerosol formation from the oxidation of toluene by chlorine atoms, Atmos. Environ., 42, 7348-7359, doi:10.1016/j.atmosenv.2008.07.014, 2008.

Callaghan, A. H., Stokes, M. D., and Deane, G. B.: The effect of water temperature on air entrainment, bubble plumes, and surface foam in a laboratory breaking-wave analog, J. Geophys. Res.Oceans, 119, 7463-7482, doi:10.1002/2014JC010351, 2014.

Chomka, M. and Petelski, T.: Sea spray emission over the coastal zone, J. Aerosol Sci., 28, 103-104, doi:10.1016/S00218502(97)85052-5, 1997.

Crippa, M., Janssens-Maenhout, G., Dentener, F., Guizzardi, D., Sindelarova, K., Muntean, M., Van Dingenen, R., and Granier, C.: Forty years of improvements in European air quality: the role of EU policy-industry interplay, Atmos. Chem. Phys. Discuss., 15, 20245-20285, doi:10.5194/acpd-15-20245-2015, 2015.

Crisp, T. A., Lerner, B. M., Williams, E. J., Quinn, P. K., Bates, T. S., and Bertram, T. H.: Observations of gas phase hydrochloric acid in the polluted marine boundary layer, J. Geophys. Res.-Atmos., 119, 6897-6915, doi:10.1002/2013JD020992, 2014.

de Leeuw, G., Neele, F. P., Hill, M., Smith, M. H., and Vignati, E.: Production of sea spray aerosol in the surf zone, J. Geophys. Res.-Atmos., 105, 29397-29409, doi:10.1029/2000JD900549, 2000.

de Leeuw, G., Skjøth, C., Hertel, O., Jickells, T., Spokes, L., Vignati, E., Frohn, L., Frydendall, J., Schulz, M., Tamm, S., Sørensen, L., and Kunz, G.: Deposition of nitrogen into the North Sea, Atmos. Environ., 37, 145-165, doi:10.1016/S13522310(03)00246-2, 2003.

EMEP: EMEP Manual for Sampling and Analysis, EMEP, available at: http://www.nilu.no/projects/ccc/manual/index.html (last access: 30 October 2015), 2014.

Fuentes, E., Coe, H., Green, D., de Leeuw, G., and McFiggans, G.: On the impacts of phytoplankton-derived organic matter on the properties of the primary marine aerosol - Part 1: Source fluxes, 
Atmos. Chem. Phys., 10, 9295-9317, doi:10.5194/acp-10-92952010, 2010.

Gantt, B., Meskhidze, N., Facchini, M. C., Rinaldi, M., Ceburnis, D., and O'Dowd, C. D.: Wind speed dependent size-resolved parameterization for the organic mass fraction of sea spray aerosol, Atmos. Chem. Phys., 11, 8777-8790, doi:10.5194/acp-11-87772011, 2011.

Gantt, B., Kelly, J. T., and Bash, J. O.: Updating sea spray aerosol emissions in the Community Multiscale Air Quality (CMAQ) model version 5.0.2, Geosci. Model Dev., 8, 37333746, doi:10.5194/gmd-8-3733-2015, 2015.

Gathman, S. G. and Hoppel, W. A.: Surf electrification, J. Geophys. Res., 75, 4525-4529, doi:10.1029/JC075i024p04525, 1970.

Geyer, B.: High-resolution atmospheric reconstruction for Europe 1948-2012: coastDat2, Earth Syst. Sci. Data, 6, 147-164, doi:10.5194/essd-6-147-2014, 2014

Geyer, B. and Rockel, B.: coastDat-2 COSMO-CLM Atmospheric Reconstruction, World Data Center for Climate (WDCC), Hamburg, Germany, doi:10.1594/WDCC/coastDat-2_COSMOCLM, 2013.

Gong, S. L.: A parameterization of sea-salt aerosol source function for sub- and super-micron particles, Global Biogeochem. Cy., 17, 1097, doi:10.1029/2003GB002079, 2003.

HELCOM: Airborne nitrogen loads to the Baltic Sea, Tech. rep., Helsinki Commission, Baltic Marine Environment Protection Commission, available at: http://www.helcom.fi/Lists/Publications/Airborne nitrogen loads to the Baltic Sea.pdf (last access: 11 January 2016), 2005.

Hertel, O., Skjøth, C. A., Frohn, L., Vignati, E., Frydendall, J., de Leeuw, G., Schwarz, U., and Reis, S.: Assessment of the atmospheric nitrogen and sulphur inputs into the North Sea using a Lagrangian model, Phys. Chem. Earth, Pt. A/B/C, 27, 15071515, doi:10.1016/S1474-7065(02)00153-5, 2002.

Huijnen, V., Williams, J., van Weele, M., van Noije, T., Krol, M., Dentener, F., Segers, A., Houweling, S., Peters, W., de Laat, J., Boersma, F., Bergamaschi, P., van Velthoven, P., Le Sager, P., Eskes, H., Alkemade, F., Scheele, R., Nédélec, P., and Pätz, H.-W.: The global chemistry transport model TM5: description and evaluation of the tropospheric chemistry version 3.0, Geosci. Model Dev., 3, 445-473, doi:10.5194/gmd-3-445-2010, 2010.

Im, U.: Impact of sea-salt emissions on the model performance and aerosol chemical composition and deposition in the East Mediterranean coastal regions, Atmos. Environ., 75, 329-340, doi:10.1016/j.atmosenv.2013.04.034, 2013.

Jaeglé, L., Quinn, P. K., Bates, T. S., Alexander, B., and Lin, J.-T.: Global distribution of sea salt aerosols: new constraints from in situ and remote sensing observations, Atmos. Chem. Phys., 11, 3137-3157, doi:10.5194/acp-11-3137-2011, 2011.

Kelly, J. T., Bhave, P. V., Nolte, C. G., Shankar, U., and Foley, K. M.: Simulating emission and chemical evolution of coarse seasalt particles in the Community Multiscale Air Quality (CMAQ) model, Geosci. Model Dev., 3, 257-273, doi:10.5194/gmd-3257-2010, 2010.

Kelly, J. T., Baker, K. R., Nowak, J. B., Murphy, J. G., Markovic, M. Z., VandenBoer, T. C., Ellis, R. A., Neuman, J. A., Weber, R. J., Roberts, J. M., Veres, P. R., de Gouw, J. A., Beaver, M. R., Newman, S., and Misenis, C.: Fine-scale simulation of ammonium and nitrate over the South Coast Air Basin and San Joaquin Valley of California dur- ing CalNex-2010, J. Geophys. Res.-Atmos., 119, 3600-3614, doi:10.1002/2013JD021290, 2014.

Knipping, E. M. and Dabdub, D.: Impact of chlorine emissions from sea-salt aerosol on coastal urban ozone, Environ. Sci. Technol., 37, 275-284, doi:10.1021/es025793z, 2003.

Langner, J., Andersson, C., and Engardt, M.: Atmospheric input of nitrogen to the Baltic Sea basin: present situation, variability due to meteorology and impact of climate change, Boreal Environ. Res., 14, 226-237, 2009.

Lavender, S., Jackson, T., and Sathyendranath, S.: The Ocean Colour Climate Change Initiative - merging ocean colour observations seamlessly, Ocean Challenge, 21, 29-31, 2015.

Lewis, E. R. and Schwartz, S. E.: Sea Salt Aerosol Production: Mechanisms, Methods, Measurements and Models - A Critical Review, vol. 152, AGU, Washington, D. C., USA, doi:10.1029/GM152, 2004.

Liu, Y., Zhang, S., Fan, Q., Wu, D., Chan, P., Wang, X., Fan, S., Feng, Y., and Hong, Y.: Accessing the Impact of Sea-Salt Emissions on Aerosol Chemical Formation and Deposition over Pearl River Delta, China, Aerosol Air Qual. Res., 15, 2232-2245, doi:10.4209/aaqr.2015.02.0127, 2015.

Lövblad, G., Tarrasón, L., Tørseth, K., and Dutchak, S.: EMEP Assessment Part I - European Perspective, Tech. rep., Norwegian Meteorological Institute, Oslo, Norway, N-313, 2004.

Manders, A., Schaap, M., Querol, X., Albert, M., Vercauteren, J., Kuhlbusch, T., and Hoogerbrugge, R.: Sea salt concentrations across the European continent, Atmos. Environ., 44, 2434-2442, doi:10.1016/j.atmosenv.2010.03.028, 2010.

Martensson, E. M., Nilsson, E. D., de Leeuw, G., Cohen, L. H., and Hansson, H.-C.: Laboratory simulations and parameterization of the primary marine aerosol production, J. Geophys. Res.-Atmos., 108, 4297, doi:10.1029/2002JD002263, 2003.

Matthäus, W., Nehring, D., Lass, H. U., Nausch, G., Nagel, K., and Siegel, H.: Hydrographisch-chemische Zustandseinschätzung der Ostsee 1996, Marine Science Reports 24, Leibniz Institute for Baltic Sea Research Warnemünde, available at: http://www.iowarnemuende.de/tl_files/forschung/meereswissenschaftlicheberichte/mebe24_1997-zustand-hc.pdf (last access: 2 February 2016), 1997.

Miao, J.-F., Wyser, K., Chen, D., and Ritchie, H.: Impacts of boundary layer turbulence and land surface process parameterizations on simulated sea breeze characteristics, Ann. Geophys., 27, 2303-2320, doi:10.5194/angeo-27-2303-2009, 2009.

Monahan, E. C. and Muircheartaigh, I. O.: Optimal power-law description of oceanic whitecap coverage dependence on wind speed, J. Phys. Oceanogr., 10, 2094-2099, doi:10.1175/15200485(1980)010<2094:OPLDOO>2.0.CO;2, 1980.

Monahan, E. C., Davidson, K. L., and Spiel, D. E.: Whitecap aerosol productivity deduced from simulation tank measurements, J. Geophys. Res.-Oceans, 87, 8898-8904, doi:10.1029/JC087iC11p08898, 1982.

Monahan, E. C., Spiel, D. E., and Davidson, K. L.: A Model of Marine Aerosol Generation via Whitecaps and Wave Disruption, Oceanographic Sciences Library, Springer, Dordrecht, the Netherlands, 167-174, 1986.

Nausch, G., Feistel, R., Umlauf, L., Nagel, K., and Siegel, H.: Hydrographisch-chemische Zustandseinschätzung der Ostsee 2008, Marine Science Reports 77, Leibniz Institute for Baltic Sea Research Warnemünde, available at: http://www.io- 
warnemuende.de/tl_files/forschung/meereswissenschaftlicheberichte/mebe77_2008-zustand-hc-und-schwermetalle.pdf (last access: 2 February 2016), 2009.

Nenes, A., Pandis, S. N., and Pilinis, C.: ISORROPIA: A New Thermodynamic Equilibrium Model for Multiphase Multicomponent Inorganic Aerosols, Aquat. Geochem., 4, 123-152, doi:10.1023/A:1009604003981, 1998.

Nenes, A., Pandis, S. N., and Pilinis, C.: Continued development and testing of a new thermodynamic aerosol module for urban and regional air quality models, Atmos. Environ., 33, 15531560, doi:10.1016/S1352-2310(98)00352-5, 1999.

Norman, M. and Leck, C.: Distribution of marine boundary layer ammonia over the Atlantic and Indian Oceans during the Aerosols99 cruise, J. Geophys. Res.-Atmos., 110, D16302, doi:10.1029/2005JD005866, 2005.

Otte, T. L. and Pleim, J. E.: The Meteorology-Chemistry Interface Processor (MCIP) for the CMAQ modeling system: updates through MCIPv3.4.1, Geosci. Model Dev., 3, 243-256, doi:10.5194/gmd-3-243-2010, 2010.

Ovadnevaite, J., Manders, A., de Leeuw, G., Ceburnis, D., Monahan, C., Partanen, A.-I., Korhonen, H., and O'Dowd, C. D.: A sea spray aerosol flux parameterization encapsulating wave state, Atmos. Chem. Phys., 14, 1837-1852, doi:10.5194/acp-14-18372014, 2014.

Paulot, F., Jacob, D. J., Johnson, M. T., Bell, T. G., Baker, A. R., Keene, W. C., Lima, I. D., Doney, S. C., and Stock, C. A.: Global oceanic emission of ammonia: constraints from seawater and atmospheric observations, Global Biogeochem. Cy., 29, 11651178, doi:10.1002/2015GB005106, 2015.

Salter, M. E., Zieger, P., Acosta Navarro, J. C., Grythe, H., Kirkevåg, A., Rosati, B., Riipinen, I., and Nilsson, E. D.: An empirically derived inorganic sea spray source function incorporating sea surface temperature, Atmos. Chem. Phys., 15, 1104711066, doi:10.5194/acp-15-11047-2015, 2015.

Sarwar, G., Luecken, D., and Yarwood, G.: Chapter 2.9 Developing and implementing an updated chlorine chemistry into the community multiscale air quality model, in: Air Pollution Modeling and Its Application XVIII, edited by: Borrego, C. and Renner, E., vol. 6 of Developments in Environmental Science, 168176, Elsevier, Amsterdam, the Netherlands, doi:10.1016/S14748177(07)06029-9, 2007.

Schlünzen, K. H. and Sokhi, R. S.: Joint Report of COST Action 728 and GURME. Overview of Tools and Methods for Meteorological and Air Pollution Mesoscale Model Evaluation and User Training, WMO TD No. 1457, WMO, Geneva, Switzerland, 2008.
Schrum, C. and Backhaus, J. O.: Sensitivity of atmosphereocean heat exchange and heat content in the North Sea and the Baltic Sea, Tellus A, 51, 526-549, doi:10.1034/j.16000870.1992.00006.x, 1999.

Seinfeld, J. H. and Pandis, S. N.: Atmospheric Chemistry and Physics: from Air Pollution to Climate Change, 2nd edn., WileyInterscience, Hoboken, New Jersey, USA, 2006.

Spada, M., Jorba, O., Pérez García-Pando, C., Janjic, Z., and Baldasano, J. M.: Modeling and evaluation of the global sea-salt aerosol distribution: sensitivity to size-resolved and sea-surface temperature dependent emission schemes, Atmos. Chem. Phys., 13, 11735-11755, doi:10.5194/acp-13-11735-2013, 2013.

Tanaka, P. L., Allen, D. T., McDonald-Buller, E. C., Chang, S., Kimura, Y., Mullins, C. B., Yarwood, G., and Neece, J. D.: Development of a chlorine mechanism for use in the carbon bond IV chemistry model, J. Geophys. Res.-Atmos., 108, 4145, doi:10.1029/2002JD002432, 2003.

Tian-Kunze, X., Kaleschke, L., Weller, R., König-Langlo, G., Wagenbach, D., Rast, S., Santos, G., Richter, A., and Begoin, M.: Sea ice as a source of sea salt aerosol: A trajectory study of 25 years of year-round sea salt aerosol record at Neumayer, Antarctica, in: Geophysical Research Abstracts, Vol. 11, EGU 2009, Vienna, Austria, p. 8934, 2009.

Whitten, G. Z., Heo, G., Kimura, Y., McDonald-Buller, E., Allen, D. T., Carter, W. P., and Yarwood, G.: A new condensed toluene mechanism for Carbon Bond: CB05-TU, Atmos. Environ., 44, 5346-5355, doi:10.1016/j.atmosenv.2009.12.029, 2010.

Yang, X., Pyle, J. A., and Cox, R. A.: Sea salt aerosol production and bromine release: Role of snow on sea ice, Geophys. Res. Lett., 35, L16815, doi:10.1029/2008GL034536, 2008.

Yarwood, G., Rao, S., Yocke, M., and Whitten, G. Z.: Updates to the Carbon Bond Chemical Mechanism: CB05, Final report to project rt-04-00675, U.S. Environmental Protection Agency, Research Triangle Park, NC 27703, USA, 2005.

Zhang, K. M., Knipping, E. M., Wexler, A. S., Bhave, P. V., and Tonnesen, G. S.: Size distribution of sea-salt emissions as a function of relative humidity, Atmos. Environ., 39, 3373-3379, doi:10.1016/j.atmosenv.2005.02.032, 2005. 